\title{
Cordination Compound of Dimethyltin(IV) with N,N,N'N'- Tetraethylethylenediamine: Speciation and Theoretical approach
}

\author{
Safaa Said Hassan ${ }^{1}$, Mohamed Mohamed Shoukry ${ }^{* 1,2}$, Abdel Aziz Qasem Jbarah ${ }^{3}$ \\ ${ }^{1}$ Department of Chemistry, Faculty of Science, Cairo University, Giza, Egypt. \\ ${ }^{2}$ Department of Chemistry, Faculty of Science, Islamic University, Al-Madinah, Saudi Arabia. \\ ${ }^{3}$ Chemistry Department, College of Science, Al-Hussein Bin Talal University, Ma'an, Jordan.
}

*Corresponding author: Mohamed Mohamed Shoukry, email: shoukrymm@hotmail.com

Received August 6 $6^{\text {th }}, 2019$; Accepted January 21 $1^{\text {th }}, 2020$.

DOI: http://dx.doi.org/10.29356/jmcs.v64i2.1079

\begin{abstract}
The formation equilibria of the dimethyltin(IV) complexes with of N,N,N',N'tetraethylethylenediamine ( $\left.\mathrm{Et}_{4} \mathrm{en}\right)$ in solution were investigated. The stoichiometry and stability constants of the complexes formed in solution phase were determined at different temperatures $\left(15^{\circ} \mathrm{C}-35^{\circ} \mathrm{C}\right)$ and in solutions of dioxane-water mixtures of different compositions $(15 \%-62.5 \%)$. The accepted model is composed of the 110,111, 11-1 and 11-2 species. The thermodynamic parameters $\Delta \mathrm{H}^{\circ}$ and $\Delta \mathrm{S}^{\circ}$ associated with the protonation of $\mathrm{N}, \mathrm{N}, \mathrm{N}^{\prime}, \mathrm{N}^{`}$-tetraethylethylendiamine (Et $\mathrm{en}$ ) and its complex formation with the dimethyltin(IV) species were determined. The complex formation reaction is exothermic. The equilibrium constant for the displacement of N,N,N',N'-tetraethylethylenediamine coordinated to dimethyltin(IV) by some selected DNA constituents was calculated. The $\mathrm{K}_{\text {eq }}$ values clearly indicate the ability of DNA to displace the coordinated $\mathrm{Et}_{4}$ en from its dimethyltin(IV) complex. The nucleotides IMP and GMP have the highest values. The DFT/B3LYP method was used for geometric optimization of the ligand and the complex using the Gaussian 09 program. Also the vibrational frequencies of the ligands and complexes were computed for the optimized geometries. The results shows that there is no imaginary frequencies as found in the calculated vibrational frequencies. The binding energies of the dimethyltin(IV) complexes were calculated. All calculated binding energy values are negative.
\end{abstract}

Keywords: Dimethyltin(IV); N,N,N',N'-tetraethylethylenediamine; stability constants; DFT calculation.

Resumen. El equilibrio de formación de complejos de dimetilestaño(IV) con N,N,N',N'-tetraetiletilenediamina (Et $t_{4}$ en) fue investigado. La estequiometria y constantes de estabilidad de los complejos formados en solución se determinaron a diferentes temperaturas $\left(15^{\circ} \mathrm{C}-35^{\circ} \mathrm{C}\right)$ y en disoluciones de dioxano/agua con diferentes proporciones $(15 \%-62.5 \%)$. El modelo aceptado está constituido de las especies 110, 111, 11-1 y 11-2. Los parámetros termodinámicos $\Delta \mathrm{H}^{\circ}$ and $\Delta \mathrm{S}^{\circ}$ asociados con la protonación de la $\mathrm{N}, \mathrm{N}, \mathrm{N}^{\prime}, \mathrm{N}^{\prime}$-tetraetiletilenediamina (Et 4 en) y la formación de sus complejos con dimetilestaño(IV) fueron determinados. La reacciónde la formación de los complejos es exotérmica. Las constantes de equilibrio del desplazamiento de la N,N,N',N'tetraetiletilenediamina coordinada al dimetilestaño(IV) con diferentes fragmentos de la ADN fueron calculadas. Los valores $\mathrm{K}_{\mathrm{eq}}$ indican claramente la capacidad de la $\mathrm{ADN}$ de sustituir a la Et 4 en de su complejo de dimetilestaño(IV). Los nucleótidos IMP y GMP presentaron los valores más altos. El método DFT/B3LYP fue utilizado para la optimización geométrica del ligante y del complejo utilizando el programa Gaussian 09. Asimismo, se calcularon las frecuencias vibracionales para las geometrías optimizadas de los ligantes y complejos. Los resultados mostraron que todas las frecuencias vibracionales calculadas son reales. También se 
calcularon los valores de energías de enlace para los complejos de dimetilestaño(IV) resultando en valores negativos.

Palabras clave: Dimetilestaño(IV); N,N,N',N'-tetraetiletilenediamina; constante de estabilidad; cálculos DFT.

\section{Introduction}

The biological activity of organotin(IV) compounds and their use as metallopharmaceuticals has been reported [1-13]. A tremendous research is directed towards the design of non-platinum chemotherapeutics with the aim to optimize the features of classical platinum drugs constituting the basic cisplatin framework viz. their toxic side effects, inherent intrinsic resistance and high cost [14]. Diorganotin(IV) complexes are acting as potential antitumours. They exhibit promise activity against many tumour cell lines [15-19]. Numerous diorganotin(IV) derivatives have been found to exhibit high in vivo cytotoxicity against P388 lymphocytic leukaemia.

The antitumour action mechanism is still unclear, although some evidence is consistent with their binding directly to DNA. The antituour activity of the organotin(IV) complex $\mathrm{R}_{2} \mathrm{SnX}_{2} \mathrm{~L}$ is depending on the group attached to the tin atom, leaving groups (X) and the coordinated ligand (L). The coordinated ligand favours in some way the transport of the drug into cells, and the antitumour activity would be exerted by the diorganotin(IV) ion released from the complex [20]. The released diorganotin(IV) species would interact with nucleic acids, similarly as in the case of the widely used anticancer drug cisplatin. Therefore, there is a relationship between the stability of the organotin(IV) complexes and their antitumour activity. In conjunction with our previous studies on organotin(IV) complexes [21-26] the present paper aims to study the dimethyltin(IV) complexes with $\mathrm{N}, \mathrm{N}, \mathrm{N}^{\prime}, \mathrm{N}^{\prime}$-tetraethylethylene diamine to have information regarding the plausible interaction mechanism toward DNA fragment. The four ethyl groups attached to ethylenediamine nitrogen atoms may undergo hydrophobic interaction with the methyl groups of tin(IV) moiety. Such interaction may increase the stability of the formed complex. Also, the four ethyl groups of Et $t_{4}$ n will increase the hydrophobic nature of the complex, which will facilitate the dimethyltin(IV) complex to get into the cell. Density functional theory (DFT) calculations for geometry optimization and vibrational frequencies of all complexes and ligands were reported.

\section{Experimental}

\section{Materials and Reagents}

Dimethyltin(IV) dichloride (DMT) was obtained from Merck Chem.Co. The ligand N,N,N',N'tetraethylethylenediamine was supplied by Sigma Chem. Co., 1,4-Dioxane was provided by Aldrich Chem. Co. Sodium hydroxide solutions were prepared by diluting the content of BDH concentrated volumetric solutions vials. $\mathrm{NaOH}$ solutions were frequently checked by titration against potassium hydrogen phthalate.

\section{Procedure and Measuring Techniques}

A Metrohm 686 titroprocessor was used for the potentiometric titrations. The titroprocessor is equipped with a 665 dosimat (Switzerland-Herisaue) and a Metrohm glass-calomel combined electrode is used. NBS standard buffer solutions [27] were used to calibrate the titroprocessor and electrode. The temperature of the titrated solutions was adjusted by circulating thermostatically controlled water through the jacket of a titration vessel. Sodium nitrate was used to adjust the ionic strength to $0.1 \mathrm{~mol} \mathrm{dm}^{-3}$. All titrations were performed under a nitrogen atmosphere. N,N,N',N'-tetraethylethylenediamine solution was prepared in the protonated form by dissolving in $\mathrm{HNO}_{3}$ solution. The protonation constants of Eten were determined by titrating $1.25 \mathrm{mmol}$. The hydrolysis constants of dimethyltin(IV) were determined by titrating $1.25 \mathrm{mmol}$. The formation constants of Et 4 en complexes with dimethyltin(IV) were determined by titrating solution mixture of $E_{4}$ en $(1.25 \mathrm{mmol})$ and dimethyltin(IV) $(1.25 \mathrm{mmol})$. The volume of each titrated solution mixtures is reached 
to $40 \mathrm{~mL}$ and the ionic strength was $0.1 \mathrm{~mol}^{\mathrm{dm}} \mathrm{dm}^{-3}$ (adjusted with $\mathrm{NaNO}_{3}$ ). $0.05 \mathrm{~mol} . \mathrm{dm}^{-3} \mathrm{NaOH}$ solution was used as titrant. The $\mathrm{pK}_{\mathrm{w}}$ values of solution mixtures of dioxane- $\mathrm{H}_{2} \mathrm{O}$ were estimated as reported previously $[28,29]$. In this procedure various amounts of standard $\mathrm{NaOH}$ solution were added to a $0.10 \mathrm{~mol} . \mathrm{dm}^{-3} \mathrm{NaNO}_{3}$ solution. From the amount of base added, $\left[\mathrm{OH}^{-}\right]$was calculated. $\left[\mathrm{H}^{+}\right]$was calculated from the $\mathrm{pH}$ value. The values obtained in this way for $\log \left[\mathrm{OH}^{-}\right]\left[\mathrm{H}^{+}\right]\left(\log \mathrm{K}_{\mathrm{w}}\right)$ are $-14.23,-14.50,-14.92,-15.12$ and -15.63 for 25.0 , $37.5,50.0,62.5$ and $75.0 \%$ dioxane in $\mathrm{H}_{2} \mathrm{O}$, respectively.

The titration data were processed to evaluate the equilibrium constants expressed by Eq. 1 and Eq. 2 .

$$
\begin{aligned}
& \mathrm{pM}+\mathrm{qL}+\mathrm{rH} \rightleftharpoons \mathrm{MpLqHr} \\
& \beta_{\mathrm{pqr}}=\frac{\left[\mathrm{M}_{\mathrm{p}} \mathrm{L}_{\mathrm{q}} \mathrm{H}_{\mathrm{r}}\right]}{[\mathrm{M}]^{\mathrm{p}}[\mathrm{L}]^{\mathrm{q}}[\mathrm{H}]^{\mathrm{r}}}
\end{aligned}
$$

Where $\mathrm{M}, \mathrm{L}$ and $\mathrm{H}$ stand for dimethyltin(IV), Et 4 en and proton respectively. The compound of general formula $\mathrm{M}_{\mathrm{p}} \mathrm{L}_{\mathrm{q}} \mathrm{H}_{\mathrm{r}}$ formed is expressed by the coefficients $\mathrm{p}, \mathrm{q}$ and $\mathrm{r}$, where $\mathrm{M}, \mathrm{L}$ and $\mathrm{H}$ stand for dimethyltin(IV), $\mathrm{Et}_{4} \mathrm{en}$ and proton respectively. The formation constants were evaluated using the computer program MINIQUAD-75 [30]. The stoichiometry and formation constants of the complexes formed were determined by trying various possible models of different composition. The accepted model is giving the best statistical fit and chemically consistent with the magnitude of various residuals, as reported previously [30]. Tables 1 and 2 include the formation constants and their standard deviation as obtained from the MINIQUAD output. The speciation diagrams were evaluated using the program SPECIES [31].

\begin{tabular}{|c|c|c|c|c|c|c|}
\hline System ${ }^{\mathrm{a}}$ & $\operatorname{Temp}\left({ }^{\circ} \mathrm{C}\right)$ & $\mathbf{p}$ & $\mathbf{q}$ & $\mathbf{r}^{\mathbf{b}}$ & $\log \beta^{c}$ & $S^{d}$ \\
\hline \multirow{7}{*}{ DMT } & \multirow{7}{*}{15} & 1 & 0 & -1 & $-3.56(0.01)$ & \multirow[t]{7}{*}{$5.4 \mathrm{E}-8$} \\
\hline & & 1 & 0 & -2 & $-9.05(0.01)$ & \\
\hline & & 1 & 0 & -3 & $-19.79(0.04)$ & \\
\hline & & 1 & 0 & -4 & $-30.41(0.04)$ & \\
\hline & & 2 & 0 & -2 & $-4.23(0.01)$ & \\
\hline & & 2 & 0 & -3 & $-9.52(0.01)$ & \\
\hline & & 2 & 0 & -4 & $-15.23(0.01)$ & \\
\hline \multirow{7}{*}{ DMT-Et $t_{4}$ n } & \multirow{7}{*}{15} & 0 & 1 & 1 & $9.94(0.01)$ & \multirow[t]{2}{*}{$1.5 \mathrm{E}-8$} \\
\hline & & 0 & 1 & 2 & $16.80(0.01)$ & \\
\hline & & 1 & 1 & 0 & $11.71(0.03)$ & \multirow[t]{5}{*}{$8.9 \mathrm{E}-10$} \\
\hline & & 1 & 2 & 0 & $18.53(0.06)$ & \\
\hline & & 1 & 1 & 1 & $16.69(0.05)$ & \\
\hline & & 1 & 1 & -1 & $5.32(0.05)$ & \\
\hline & & 1 & 1 & -2 & $-2.52(0.05)$ & \\
\hline \multirow{7}{*}{ DMT } & \multirow{7}{*}{20} & 1 & 0 & -1 & $-3.31(0.01)$ & \multirow[t]{7}{*}{$6.1 \mathrm{E}-8$} \\
\hline & & 1 & 0 & -2 & $-8.64(0.01)$ & \\
\hline & & 1 & 0 & -3 & $-19.27(0.05)$ & \\
\hline & & 1 & 0 & -4 & $-30.71(0.02)$ & \\
\hline & & 2 & 0 & -2 & $-3.77(0.01)$ & \\
\hline & & 2 & 0 & -3 & $-8.91(0.02)$ & \\
\hline & & 2 & 0 & -4 & $-14.44(0.01)$ & \\
\hline
\end{tabular}

Table 1. Formation constants of dimethyltin (IV) complexes with Et 4 en in water at different temperatures. 


\begin{tabular}{|c|c|c|c|c|c|c|}
\hline DMT-Et 4 en & 20 & $\begin{array}{l}0 \\
0 \\
1 \\
1 \\
1 \\
1 \\
1 \\
\end{array}$ & $\begin{array}{l}1 \\
1 \\
1 \\
2 \\
1 \\
1 \\
1\end{array}$ & $\begin{array}{c}1 \\
2 \\
0 \\
0 \\
1 \\
-1 \\
-2 \\
\end{array}$ & $\begin{array}{c}9.81(0.01) \\
16.54(0.01) \\
11.52(0.04) \\
18.23(0.05) \\
16.47(0.05) \\
5.17(0.04) \\
-2.41(0.04)\end{array}$ & $\begin{array}{l}1.4 \mathrm{E}-8 \\
3.2 \mathrm{E}-8\end{array}$ \\
\hline DMT & 25 & $\begin{array}{l}1 \\
1 \\
1 \\
1 \\
2 \\
2 \\
2 \\
2\end{array}$ & $\begin{array}{l}0 \\
0 \\
0 \\
0 \\
0 \\
0 \\
0\end{array}$ & $\begin{array}{l}-1 \\
-2 \\
-3 \\
-4 \\
-2 \\
-3 \\
-4\end{array}$ & $\begin{array}{c}-3.03(0.01) \\
-8.21(0.01) \\
-18.73(0.03) \\
-29.54(0.02) \\
-3.12(0.01) \\
-8.13(0.02) \\
-13.59(0.02)\end{array}$ & $4.3 \mathrm{E}-8$ \\
\hline $\mathrm{DMT}^{-\mathrm{Et}_{4} \mathrm{en}}$ & 25 & $\begin{array}{l}0 \\
0 \\
1 \\
1 \\
1 \\
1 \\
1 \\
\end{array}$ & $\begin{array}{l}1 \\
1 \\
1 \\
2 \\
1 \\
1 \\
1\end{array}$ & $\begin{array}{c}1 \\
2 \\
0 \\
0 \\
1 \\
-1 \\
-2\end{array}$ & $\begin{array}{c}9.65(0.01) \\
16.22(0.02) \\
11.31(0.02) \\
17.80(0.04) \\
16.23(0.04) \\
5.00(0.04) \\
-2.24(0.05) \\
\end{array}$ & $\begin{array}{l}3.4 \mathrm{E}-8 \\
4.1 \mathrm{E}-10\end{array}$ \\
\hline DMT & 30 & $\begin{array}{l}1 \\
1 \\
1 \\
1 \\
2 \\
2 \\
2 \\
\end{array}$ & $\begin{array}{l}0 \\
0 \\
0 \\
0 \\
0 \\
0 \\
0\end{array}$ & $\begin{array}{l}-1 \\
-2 \\
-3 \\
-4 \\
-2 \\
-3 \\
-4\end{array}$ & $\begin{array}{c}-2.81(0.01) \\
-7.91(0.02) \\
-18.38(0.05) \\
-28.71(0.02) \\
-2.87(0.02) \\
-7.84(0.04) \\
-13.06(0.04)\end{array}$ & $6.6 \mathrm{E}-8$ \\
\hline DMT-Et 4 en & 30 & $\begin{array}{l}0 \\
0 \\
1 \\
1 \\
1 \\
1 \\
1\end{array}$ & $\begin{array}{l}1 \\
1 \\
1 \\
2 \\
1 \\
1 \\
1\end{array}$ & $\begin{array}{c}1 \\
2 \\
0 \\
0 \\
1 \\
-1 \\
-2\end{array}$ & $\begin{array}{c}9.51(0.01) \\
15.94(0.01) \\
11.08(0.03) \\
17.32(0.09) \\
15.98(0.04) \\
4.81(0.07) \\
-2.11(0.05)\end{array}$ & $\begin{array}{l}9.3 \mathrm{E}-9 \\
8.7 \mathrm{E}-10\end{array}$ \\
\hline DMT & 35 & $\begin{array}{l}1 \\
1 \\
1 \\
1 \\
2 \\
2 \\
2 \\
\end{array}$ & $\begin{array}{l}0 \\
0 \\
0 \\
0 \\
0 \\
0 \\
0\end{array}$ & $\begin{array}{l}-1 \\
-2 \\
-3 \\
-4 \\
-2 \\
-3 \\
-4\end{array}$ & $\begin{array}{c}-2.49(0.02) \\
-7.54(0.02) \\
-17.95(0.06) \\
-28.20(0.03) \\
-2.27(0.03) \\
-7.11(0.04) \\
-12.34(0.04)\end{array}$ & $6.9 \mathrm{E}-8$ \\
\hline $\mathrm{DMT}^{-\mathrm{Et}_{4} \mathrm{en}}$ & 35 & $\begin{array}{l}0 \\
0 \\
1 \\
1 \\
1 \\
1 \\
1\end{array}$ & $\begin{array}{l}1 \\
1 \\
1 \\
2 \\
1 \\
1 \\
1\end{array}$ & $\begin{array}{c}1 \\
2 \\
0 \\
0 \\
1 \\
-1 \\
-2\end{array}$ & $\begin{array}{c}9.42(0.01) \\
15.70(0.01) \\
10.90(0.05) \\
16.96(0.10) \\
15.78(0.05) \\
4.66(0.07) \\
2.90(0.05)\end{array}$ & $\begin{array}{l}1.7 \mathrm{E}-8 \\
1.1 \mathrm{E}-9\end{array}$ \\
\hline
\end{tabular}

${ }^{\mathrm{a}} \mathrm{p}, \mathrm{q}$ and $\mathrm{r}$ are the stoichiometric coefficient corresponding to organotin(IV), Et 4 en and $\mathrm{H}^{+}$, respectively; ${ }^{\mathrm{c}}$ Standard deviations are given in parentheses; ${ }^{\mathrm{d}}$ Sum of square of residuals. 
Table 2. Formation constants of dimethyltin (IV) complexes with Et $\mathrm{t}_{4} \mathrm{en}$ in dioxane-water solutions of different compositions.

\begin{tabular}{|c|c|c|c|c|c|c|}
\hline System & $\begin{array}{c}\text { Dioxane } \\
\%\end{array}$ & $\mathbf{p}$ & $\mathbf{q}$ & $\mathbf{r}^{\mathbf{a}}$ & $\log \beta^{b}$ & $\mathbf{S}^{\mathbf{c}}$ \\
\hline DMT & 12.5 & \begin{tabular}{l|l}
1 & \\
1 & \\
1 & \\
1 & \\
2 & \\
2 & \\
2 &
\end{tabular} & $\begin{array}{l}0 \\
0 \\
0 \\
0 \\
0 \\
0 \\
0\end{array}$ & $\begin{array}{l}-1 \\
-2 \\
-3 \\
-4 \\
-2 \\
-3 \\
-4\end{array}$ & $\begin{array}{c}-3.27(0.01) \\
-8.70(0.02) \\
-19.53(0.06) \\
-30.09(0.03) \\
-3.68(0.02) \\
-8.94(0.05) \\
-14.52(0.04)\end{array}$ & $1.3 \mathrm{E}-7$ \\
\hline $\mathrm{DMT}-\mathrm{Et}_{4} \mathrm{en}$ & 12.5 & $\begin{array}{l}0 \\
0 \\
1 \\
1 \\
1 \\
1 \\
1\end{array}$ & $\begin{array}{l}1 \\
1 \\
1 \\
2 \\
1 \\
1 \\
1\end{array}$ & $\begin{array}{c}1 \\
2 \\
0 \\
0 \\
1 \\
-1 \\
-2\end{array}$ & $\begin{array}{c}9.75(0.01) \\
16.40(0.02) \\
11.37(0.02) \\
18.52(0.07) \\
16.00(0.04) \\
5.00(0.07) \\
-2.14(0.05)\end{array}$ & $\begin{array}{l}1.8 \mathrm{E}-8 \\
1.5 \mathrm{E}-9\end{array}$ \\
\hline DMT & 25.0 & \begin{tabular}{l|l}
1 & \\
1 & \\
1 & \\
1 & \\
2 & \\
2 & \\
2 & \\
\end{tabular} & $\begin{array}{l}0 \\
0 \\
0 \\
0 \\
0 \\
0 \\
0\end{array}$ & $\begin{array}{l}-1 \\
-2 \\
-3 \\
-4 \\
-2 \\
-3 \\
-4 \\
\end{array}$ & $\begin{array}{c}-3.39(0.00) \\
-8.99(0.01) \\
-19.83(0.01) \\
-31.30(0.01) \\
-3.92(0.01) \\
-9.27(0.04) \\
-15.11(0.03)\end{array}$ & $1.0 \mathrm{E}-8$ \\
\hline $\mathrm{DMT}^{-E t_{4} \mathrm{en}}$ & 25.0 & $\begin{array}{l}0 \\
0 \\
1 \\
1 \\
1 \\
1 \\
1\end{array}$ & $\begin{array}{l}1 \\
1 \\
1 \\
2 \\
1 \\
1 \\
1 \\
\end{array}$ & $\begin{array}{c}1 \\
2 \\
0 \\
0 \\
1 \\
-1 \\
-2 \\
\end{array}$ & $\begin{array}{c}9.57(0.00) \\
16.02(0.01) \\
11.11(0.03) \\
18.10(0.07) \\
15.80(0.04) \\
4.84(0.10) \\
-2.31(0.06) \\
\end{array}$ & $\begin{array}{l}2.8 \mathrm{E}-9 \\
1.5 \mathrm{E}-9\end{array}$ \\
\hline DMT & 37.5 & $\begin{array}{l}1 \\
1 \\
1 \\
1 \\
2 \\
2 \\
2\end{array}$ & $\begin{array}{l}0 \\
0 \\
0 \\
0 \\
0 \\
0 \\
0\end{array}$ & $\begin{array}{l}-1 \\
-2 \\
-3 \\
-4 \\
-2 \\
-3 \\
-4\end{array}$ & $\begin{array}{c}-3.53(0.01) \\
-9.23(0.01) \\
-20.18(0.02) \\
-31.83(0.01) \\
-4.17(0.01) \\
-9.61(0.03) \\
-15.59(0.03)\end{array}$ & $1.4 \mathrm{E}-8$ \\
\hline $\mathrm{DMT}^{-E t_{4} \mathrm{en}}$ & 37.5 & \begin{tabular}{l|l}
0 \\
0 \\
1 \\
1 \\
1 \\
1 \\
1
\end{tabular} & $\begin{array}{l}1 \\
1 \\
1 \\
2 \\
1 \\
1 \\
1 \\
\end{array}$ & $\begin{array}{c}1 \\
2 \\
0 \\
0 \\
1 \\
-1 \\
-2 \\
\end{array}$ & $\begin{array}{c}9.38(0.01) \\
15.72(0.01) \\
10.72(0.02) \\
17.50(0.02) \\
15.48(0.04) \\
4.53(0.01) \\
-2.64(0.04) \\
\end{array}$ & $\begin{array}{l}1.1 \mathrm{E}-8 \\
1.3 \mathrm{E}-9\end{array}$ \\
\hline DMT & 50.0 & $\begin{array}{l}1 \\
1 \\
1 \\
1 \\
2 \\
2 \\
\end{array}$ & $\begin{array}{l}0 \\
0 \\
0 \\
0 \\
0 \\
0\end{array}$ & $\begin{array}{l}-1 \\
-2 \\
-3 \\
-4 \\
-2 \\
-3\end{array}$ & $\begin{array}{c}-3.60(0.01) \\
-9.43(0.01) \\
-20.58(0.02) \\
-32.52(0.02) \\
-4.30(0.01) \\
-9.78(0.04)\end{array}$ & $2.8 \mathrm{E}-8$ \\
\hline
\end{tabular}




\begin{tabular}{|c|c|c|c|c|c|c|}
\hline & & 2 & 0 & -4 & $-16.03(0.04)$ & \\
\hline \multirow{7}{*}{ DMT-Et $_{4} \mathrm{en}$} & \multirow{7}{*}{50.0} & 0 & 1 & 1 & $9.17(0.01)$ & \multirow[t]{2}{*}{$1.5 \mathrm{E}-8$} \\
\hline & & 0 & 1 & 2 & $15.30(0.01)$ & \\
\hline & & 1 & 1 & 0 & $10.31(0.04)$ & \multirow[t]{5}{*}{$7.5 \mathrm{E}-10$} \\
\hline & & 1 & 2 & 0 & $16.90(0.07)$ & \\
\hline & & 1 & 1 & 1 & $15.13(0.06)$ & \\
\hline & & 1 & 1 & -1 & $4.25(0.09)$ & \\
\hline & & 1 & 1 & -2 & $-2.94(0.06)$ & \\
\hline \multirow{7}{*}{ DMT } & \multirow{7}{*}{62.5} & 1 & 0 & -1 & $-3.68(0.01)$ & \multirow[t]{7}{*}{$8.7 \mathrm{E}-8$} \\
\hline & & 1 & 0 & -2 & $-9.62(0.02)$ & \\
\hline & & 1 & 0 & -3 & $-20.89(0.04)$ & \\
\hline & & 1 & 0 & -4 & $-33.26(0.05)$ & \\
\hline & & 2 & 0 & -2 & $-4.47(0.01)$ & \\
\hline & & 2 & 0 & -3 & $-9.90(0.03)$ & \\
\hline & & 2 & 0 & -4 & $-16.51(0.04)$ & \\
\hline \multirow{7}{*}{$\mathrm{DMT}-\mathrm{Et}_{4} \mathrm{en}$} & \multirow{7}{*}{62.5} & 0 & 1 & 1 & $9.04(0.01)$ & \multirow[t]{7}{*}{$1.1 \mathrm{E}-8$} \\
\hline & & 0 & 1 & 2 & $15.11(0.01)$ & \\
\hline & & 1 & 1 & 0 & $9.93(0.03)$ & \\
\hline & & 1 & 2 & 0 & $16.29(0.09)$ & \\
\hline & & 1 & 1 & 1 & $14.82(0.05)$ & \\
\hline & & 1 & 1 & -1 & $3.96(0.07)$ & \\
\hline & & 1 & 1 & -2 & $-3.26(0.06)$ & \\
\hline
\end{tabular}

${ }^{\mathrm{a}} \mathrm{p}, \mathrm{q}$ and $\mathrm{r}$ are the stoichiometric coefficient corresponding to organotin(IV), Et 4 en and $\mathrm{H}^{+}$respectively; ${ }^{\mathrm{b}}$ Standard deviations are given in parentheses; 'Sum of square of residuals.

\section{Computational Details}

For geometries optimization, the density functional theory was applied using the Gaussian09 program [32]. A full optimization of all complexes and ligands geometries were obtained using the hybrid functional B3LYP (Becke's, three-parameter exchange functional, in combination with Lee-Yang-Parr correlation function) [33-35]. The basis set used is LANL2DZ (Los Alamos National Laboratory 2 double-zeta) [36-38] for Sn metal, while $\mathrm{C}, \mathrm{H}, \mathrm{N}, \mathrm{O}$ and $\mathrm{Cl}$ were described by 6-311G* standard basis set in optimization. The GaussView 5.0 by Gaussian Inc. program was used for inspecting the input and output files generated by Gaussian09, for preprocessing, structure modification, and post processing analyses of structures, frequencies, and forces. To identify the most stable structure, the minima, a frequency analysis was performed for each stationary point. These analyses are performed to ensure that all minima have no imaginary frequencies in the vibrational mode calculations.

\section{Results and discussion}

\section{Dimethyltin(IV) complex formation equilibria}

The protonation constants of $\mathrm{N}, \mathrm{N}, \mathrm{N}^{\prime}, \mathrm{N}^{\prime}$-tetraethylethylenediamine were determined using the same experimental conditions as solvent composition, temperature and ionic strength which are used for the investigation of organotin complex equilibria. The overall protonation constants $\left(\log \beta_{11}\right.$ and $\left.\log \beta_{12}\right)$ for $E t_{4}$ en were estimated. The values obtained agree with the literature data [39] considering changes in experimental condition.

The acid-base equilibria of dimethyltin(IV) ion was investigated previously in aqueous media [40-44]. The potentiometric data in the mixed solvents used were fitted assuming a model composed of the species 10$1,10-2,10-3,10-4,10-4,20-3$ and 20-4, Table 1 . The aqua-hydroxo species (10-1) may undergo dimerization according to the general equilibrium 


\section{$2\left[(\mathrm{DMT})\left(\mathrm{H}_{2} \mathrm{O}\right)_{3}(\mathrm{OH})\right]^{+} \rightleftharpoons\left[(\mathrm{DMT})_{2}(\mathrm{HO})_{2}(\mathrm{H} 2 \mathrm{O})_{4}\right]^{2+}+2 \mathrm{H}_{2} \mathrm{O}^{+}$}

The dimerization constant $\left(\mathrm{K}_{\mathrm{d}}\right)$ can be determined by Eq. 4 .

$\log \mathrm{K}_{\mathrm{d}}=\log \beta_{202}-2 \log \beta_{10-1}$

Following the same way the dimerization constant of the species 20-4 is determined by the Eq. 5 [24].

$\log K_{d}=\log \beta_{20-4}-2 \log \beta_{10-2}$

The potentioetric titration curves of the protonated N,N,N',N'-tetraethylethylenediamine and its dimethyltin(IV) complex are compared. The complex titration curve is lower than the Et 4 en curve, Fig. 1. This corresponds to the formation of a complex species through the ionization of hydrogen ion. The titration data were fitted considering the formation of the 110,111,11-1 and 11-2 species, according to scheme 1 .
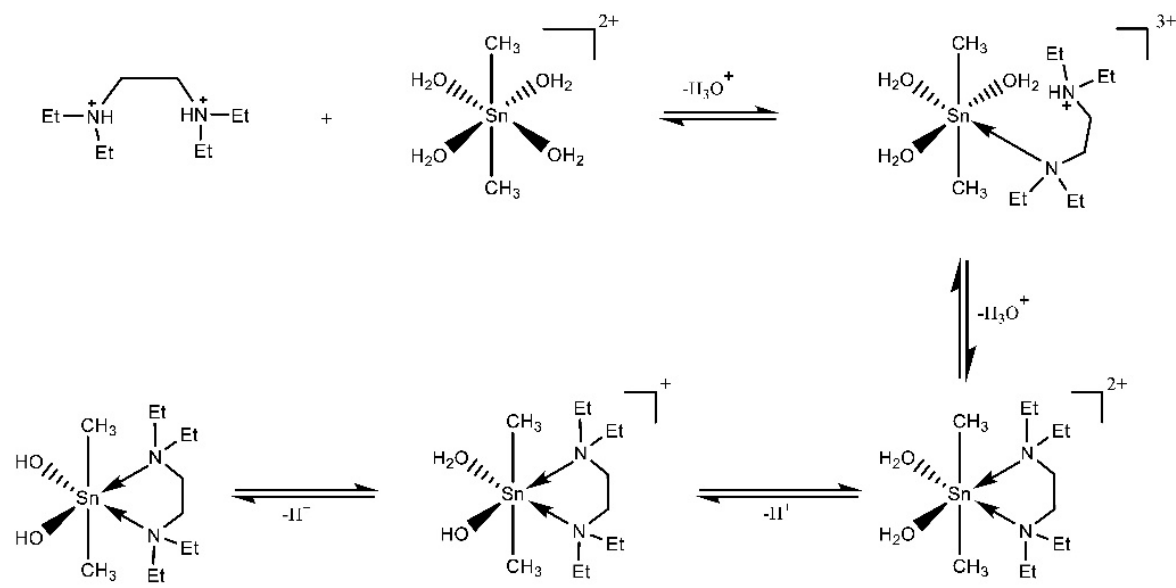

Scheme 1. Formation equilibria of dimethyltin(IV)-Et 4 en complex .

Eq. 6 and 7 [26] are used to calculate the $\mathrm{pK}_{\mathrm{a}}$ of coordinated water molecules.

$$
\begin{aligned}
& \mathrm{pK}_{\mathrm{a} 1}=\log \beta_{110^{-}} \log \beta_{11-1} \\
& \mathrm{pk}_{\mathrm{a} 2}=\log \beta_{11-1}-\log \beta_{11-2}
\end{aligned}
$$

The obtained values are 5.57 and 9.68 for $\mathrm{pK}_{\mathrm{a} 1}$ and $\mathrm{pk}_{\mathrm{a} 2}$ respectively. These are higher than those of water molecules coordinated to the free dimethyltin(IV) ion. This may be explained on the premise that 
coordination of Et 4 en will decrease the electrophilicity of tin. This will result in the coordinated water molecule will be weakly bound and consequently will be less acidic.

The speciation diagram of DMT-Et 4 en complexes is used to provide a useful picture of the coordination of organotin with $\mathrm{Et}_{4} \mathrm{en}$ as a function of $\mathrm{pH}$, Fig. 1. The protonated complex with stoichiometric coefficients 111 , predominates at lower $\mathrm{pH}$. It attains a maximum concentration of $38 \%$ at $\mathrm{pH}=3.8$. The deprotonated complex 110 starts to form at $\mathrm{pH} 3.0$ and reaches the maximum concentration of $39 \%$ at $\mathrm{pH}=5.7$. The hydrolyzed form 11-1 predominates between $\mathrm{pH}=5.7$ and 8.0 with maximum formation degree of $27 \%$ at $\mathrm{pH}$ $=6.9$. It is interesting to note that the complex species 110 and $11-1$ are predominating in the physiological $\mathrm{pH}$ range. Therefore the binding of DMT complex with DNA constituent, the main target in the chemotherapy is possible. This may be explained on the premise that the DNA constituents coordinate in the negatively charged anionic form.

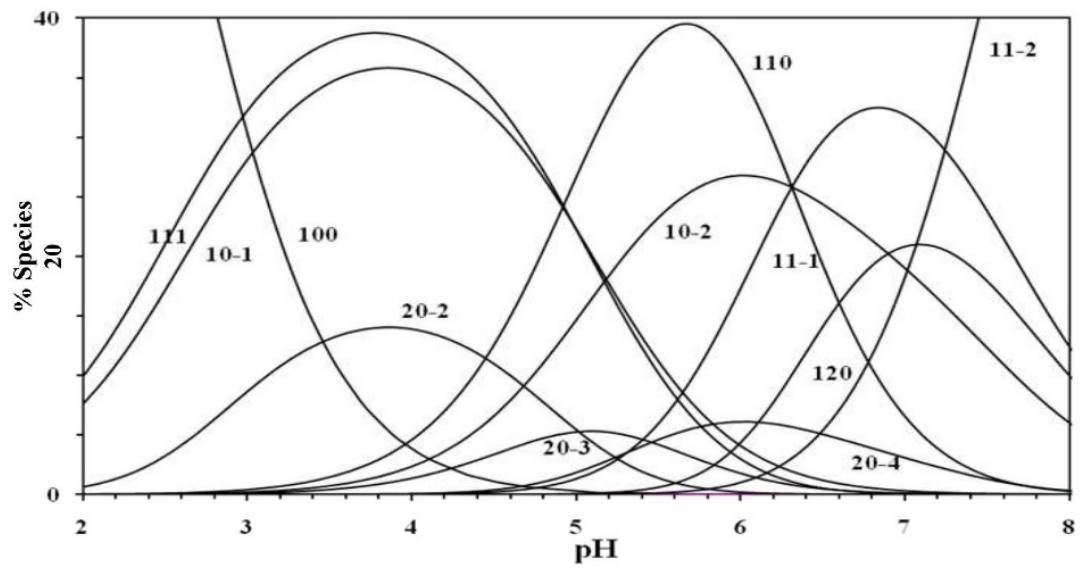

Fig. 1. Concentration distribution of various species as a function of $\mathrm{pH}$ in the DMT- Et $\mathrm{t}_{4} \mathrm{en}$ system.

\section{Effect of temperature}

The thermodynamic parameters $\Delta \mathrm{H}^{\circ}$ and $\Delta \mathrm{S}^{\circ}$ associated with the protonation of $\mathrm{N}, \mathrm{N}, \mathrm{N}^{\prime}, \mathrm{N}^{\prime}-$ tetraethylethylendiamine (Et 4 en) and its complex formation with the dimethyltin(IV) species were calculated from the temperature dependence of the data in Table 3. The plots are given in figures 2-3. These data can be employed to extrapolate the equilibrium constants to other temperatures. The main conclusions from the data can be summarized as follows:

a) The protonation reactions (8) and (10) of $\mathrm{Et}_{4} \mathrm{en}$ are exothermic and of comparable $\Delta \mathrm{H}^{\circ}$ value. Three factors affect the protonation reactions (i). The neutralization reaction, which is an exothermic process. (ii). Desolvation of ions, which is an endothermic process. (iii). The change of the conformation and the arrangements of the hydrogen bonds around the free and the protonated ligands.

b) The complexation reaction (11-15) for dimethyltin(IV) ion with Et $t_{4} \mathrm{en}$ is exothermic with negative $\Delta \mathrm{H}^{\circ}$ values, amounting to $-70.0,-137.5,-78.5$ and $-57.1 \mathrm{~kJ} \cdot \mathrm{mol}^{-1}$.

Table 3. Thermodynamic parameters for the equilibria of dimethyltin(IV) complexes. ${ }^{\mathrm{a}}$

\begin{tabular}{|c|c|c|}
\hline Equilibrium & $\Delta \mathbf{H}^{\circ}\left(\mathbf{k J m o l}^{\mathbf{1}}\right)$ & $\Delta \mathbf{S}^{\circ}\left(\mathbf{J K}^{\mathbf{1}} \mathbf{~ m o l}^{\mathbf{1}}\right)$ \\
\hline DMT $^{\mathbf{b}}$ & & \\
\hline 1$) \mathrm{M}\left(\mathrm{H}_{2} \mathrm{O}\right)_{4}{ }^{2+}+\mathrm{OH}^{-} \rightleftharpoons \mathrm{M}\left(\mathrm{H}_{2} \mathrm{O}\right)_{3}(\mathrm{OH})^{+}+\mathrm{H}_{2} \mathrm{O}$ & $40.2(0.5)$ & $344(2)$ \\
\hline 2) $\mathrm{M}\left(\mathrm{H}_{2} \mathrm{O}\right)_{3}(\mathrm{OH})^{+}+\mathrm{OH}^{-} \rightleftharpoons \mathrm{M}\left(\mathrm{H}_{2} \mathrm{O}\right)_{2}(\mathrm{OH})_{2}+\mathrm{H}_{2} \mathrm{O}$ & $-11.5(0.2)$ & $128(1)$ \\
\hline 3) $\mathrm{M}\left(\mathrm{H}_{2} \mathrm{O}\right)_{2}(\mathrm{OH})_{2}+\mathrm{OH}^{-} \rightleftharpoons \mathrm{M}\left(\mathrm{H}_{2} \mathrm{O}\right)(\mathrm{OH})_{3}{ }^{-}+\mathrm{H}_{2} \mathrm{O}$ & $-21.4(0.4)$ & $-7(1)$ \\
\hline
\end{tabular}




\begin{tabular}{|c|c|c|}
\hline 4) $\mathrm{M}\left(\mathrm{H}_{2} \mathrm{O}\right)(\mathrm{OH})_{3}{ }^{-}+\mathrm{OH}^{-} \rightleftharpoons \mathrm{M}(\mathrm{OH})_{4}{ }^{2-}+\mathrm{H}_{2} \mathrm{O}$ & $-20.9(0.4)$ & $-4(1)$ \\
\hline 5) $2 \mathrm{M}\left(\mathrm{H}_{2} \mathrm{O}\right)_{4}{ }^{2+}+2 \mathrm{OH}^{-} \quad \rightleftharpoons \mathrm{M}_{2}\left(\mathrm{H}_{2} \mathrm{O}\right)_{4}(\mathrm{OH})_{2}{ }^{2+}+4 \mathrm{H}_{2} \mathrm{O}$ & $65.0(0.8)$ & $690(7)$ \\
\hline 6) $\mathrm{M}_{2}\left(\mathrm{H}_{2} \mathrm{O}\right)_{4}(\mathrm{OH})_{2}{ }^{2+}+\mathrm{OH}^{-} \rightleftharpoons \mathrm{M}_{2}\left(\mathrm{H}_{2} \mathrm{O}\right)_{3}(\mathrm{OH})_{3}{ }^{+}+\mathrm{H}_{2} \mathrm{O}$ & $-13.0(0.3)$ & $127(1)$ \\
\hline 7) $\mathrm{M}_{2}\left(\mathrm{H}_{2} \mathrm{O}\right)_{3}(\mathrm{OH})_{3}{ }^{+}+\mathrm{OH}^{-} \rightleftharpoons \mathrm{M}_{2}\left(\mathrm{H}_{2} \mathrm{O}\right)_{2}(\mathrm{OH})_{4}+\mathrm{H}_{2} \mathrm{O}$ & $-6.1(0.1)$ & $142(1)$ \\
\hline \multicolumn{3}{|l|}{$E_{\text {eten }}$} \\
\hline $\begin{aligned} \text { 8) } \mathrm{L}+\mathrm{H}^{+} & \rightleftharpoons \mathrm{LH}^{+} \\
\text {9) } \mathrm{LH}^{+}+\mathrm{H}^{+} & \rightleftharpoons \mathrm{LH}_{2}^{2+} \\
\text { 10) } \mathrm{L}+2 \mathrm{H}^{+} & \rightleftharpoons \mathrm{LH}_{2}{ }^{2+}\end{aligned}$ & $\begin{array}{c}-45.6(0.1) \\
-45.78 \\
-95.2(0.1)\end{array}$ & $\begin{array}{c}32.0(0.3) \\
31.98 \\
-8.6(0.4)\end{array}$ \\
\hline \multicolumn{3}{|l|}{ DMT-Et $_{4} \mathrm{en}$} \\
\hline 11) $\mathrm{M}+\mathrm{L} \rightleftharpoons \mathrm{ML}$ & $-70.0(0.1)$ & $-18.6(0.3)$ \\
\hline 12) $\mathrm{M}+2 \mathrm{~L} \rightleftharpoons \mathrm{ML}_{2}$ & $-137.5(0.3)$ & $-121.4(1)$ \\
\hline 13) $\mathrm{M}+\mathrm{L}+\mathrm{H} \rightleftharpoons \mathrm{MLH}$ & $-78.5(0.1)$ & $47.1(0.3)$ \\
\hline 14) $\mathrm{M}+\mathrm{L}-\mathrm{H} \rightleftharpoons \mathrm{MLH}_{-1}$ & $-57.1(0.1)$ & $-96.0(0.3)$ \\
\hline 15) $\mathrm{M}+\mathrm{L}-2 \mathrm{H} \rightleftharpoons \mathrm{MLH}_{-2}$ & $39.5(0.2)$ & $89.2(0.8)$ \\
\hline
\end{tabular}

${ }^{a} \mathrm{M}$ denotes $\left(\mathrm{CH}_{3}\right) \mathrm{Sn}^{2+} ; \mathrm{L}$ denote; Standard deviations are given in parentheses. ${ }^{\mathrm{b}}$ hydrolysis data are from reference [51]

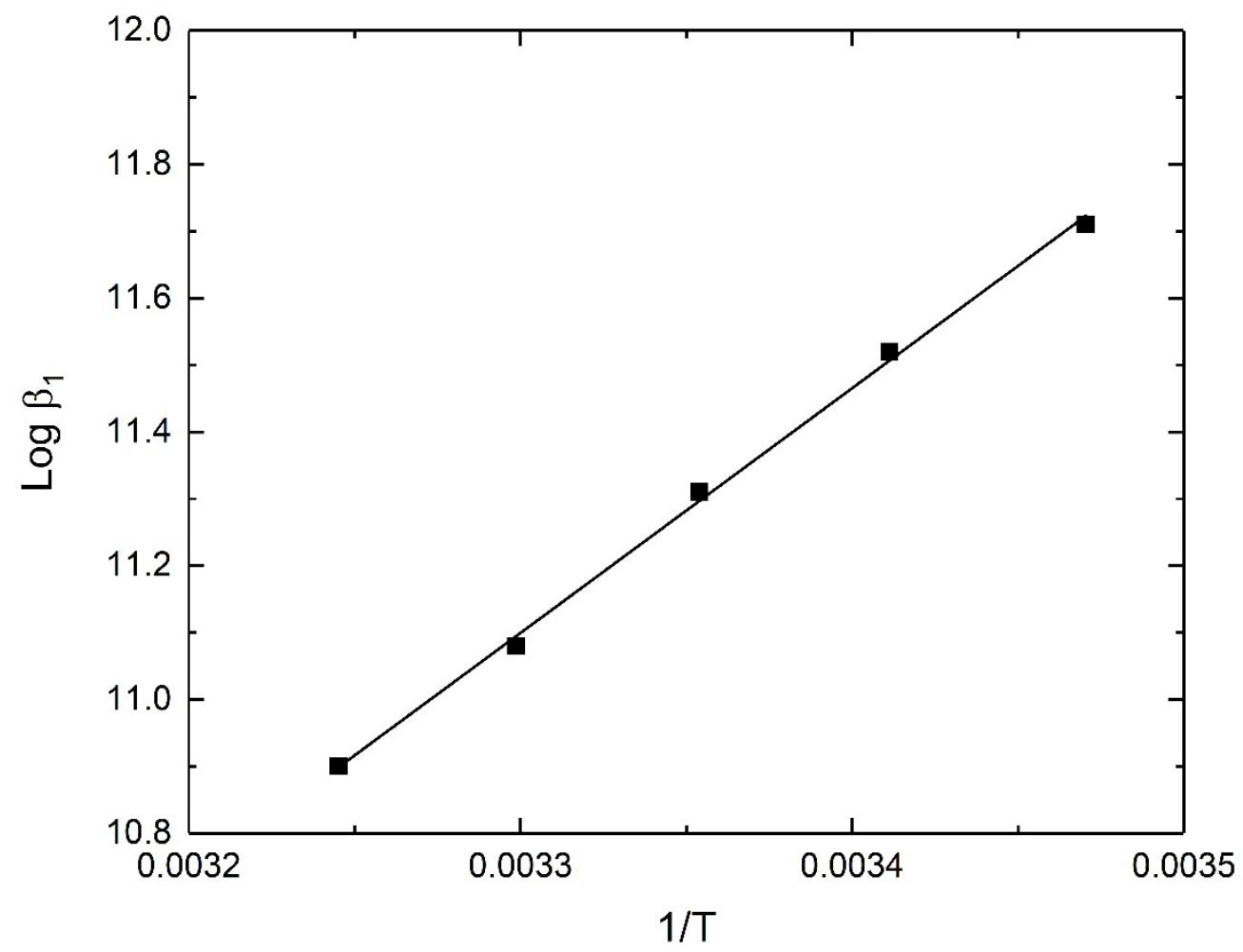

Fig. 2. Plot of $\log \beta_{1}$ vs. 1/T for $\left(\mathrm{CH}_{3}\right)_{2} \mathrm{Sn}-\mathrm{Et}_{4} \mathrm{en}$ complex. 


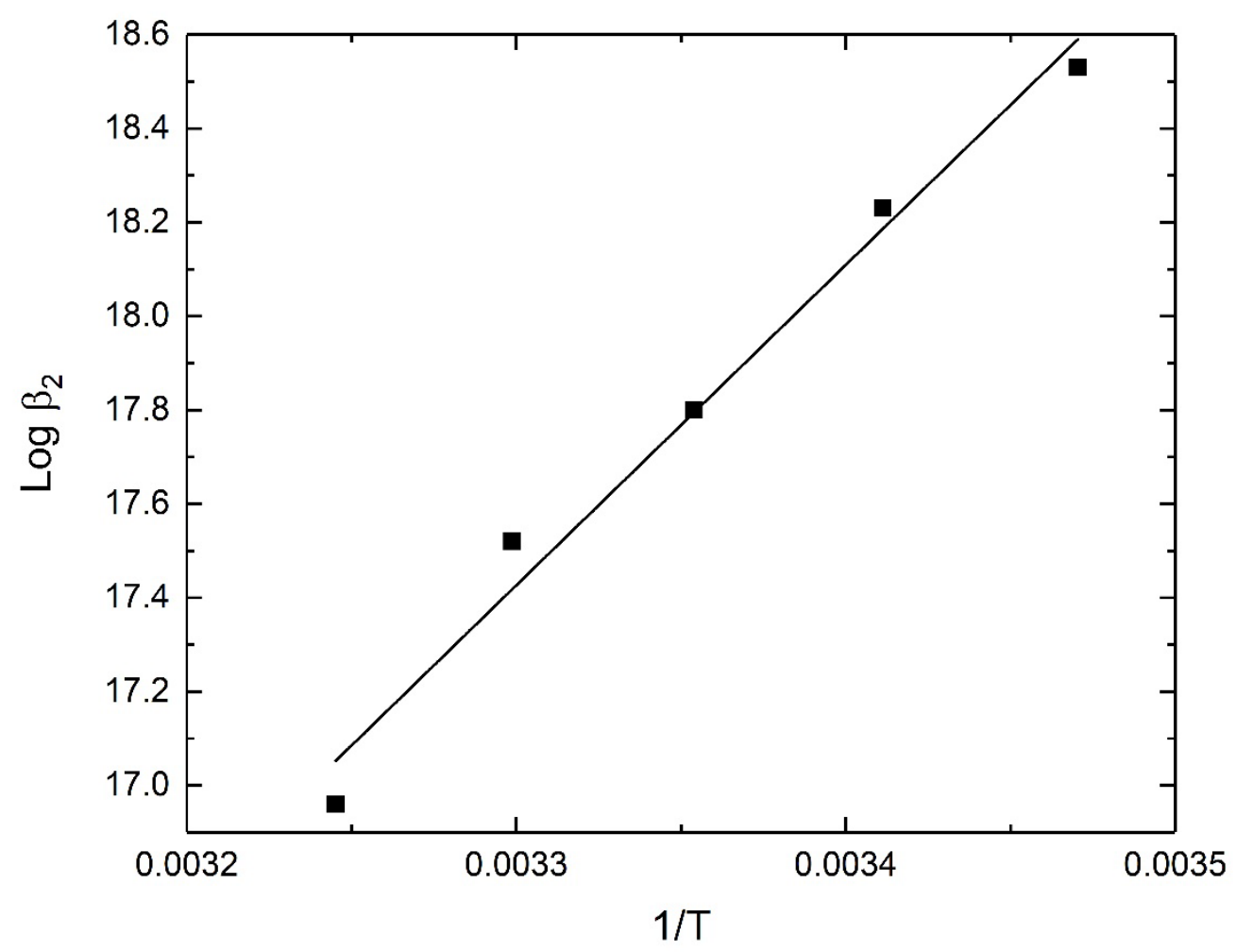

Fig. 3. Plot of $\log \beta_{2} v s$. $1 / \mathrm{T}$ for $\left(\mathrm{CH}_{3}\right)_{2} \mathrm{Sn}_{2}-\mathrm{Et}_{4}$ en complex.

\section{Effect of solvent}

It is reported that the effective dielectric constant of the surrounding of active sites cavities of enzymes and proteins $[45,46]$ is smaller , compared to in bulk water. Dielectric constants in such sites were found to be in range from 30 to $70[47,48]$. Hence by using solution media containing around 10 to $50 \%$ dioxane, one may expect to approach to some extent the situation in these biological sites. By this way one may extrapolate the data to physiological condition. Careful examination of the medium effect on the equilibrium constants reveal the following features:

a) $\mathrm{pK}_{\mathrm{a}}$ of Et $\mathrm{t}_{4} \mathrm{en}$ decrease linearly with increasing the percentage of organic solvent in the medium. This behavior is discussed based on the hydrophobic interaction between the neutral $\mathrm{Et}_{4} \mathrm{en}$ species and dioxane.

b) The pKa values of coordinated water molecules in $\left[\left(\mathrm{CH}_{3}\right)_{2} \mathrm{Sn}\left(\mathrm{OH}_{2}\right)_{4}\right]^{2+}$ increase with increasing the dioxane percentage in the medium. This may be explained on the premise that the solvent of relatively low dielectric constant will increase the electrostatic forces between proton and hydrolyzed form of DMT.

c) The formation constants for dimethyltin(IV) complexes with Et $\mathrm{t}_{4} \mathrm{en}$ decrease upon addition of dioxane to an aqueous solution of the corresponding species, figures 4-5. This can be explained by better solvation of virtually hydrophobic species $\mathrm{CH}_{3} \mathrm{Sn}^{+} / \mathrm{CH}_{3} \mathrm{SnCl}$ by dioxane through formation of coordinative bonds between O-dioxane and $\mathrm{Sn}$ centres. This leads to stabilization and modulation of solubility of dimethyltin(IV) species. This results in lowering the complex stability. This finding is in agreement with that proposed for alkyltin(IV) complexes with D-glucosamine [49]. 


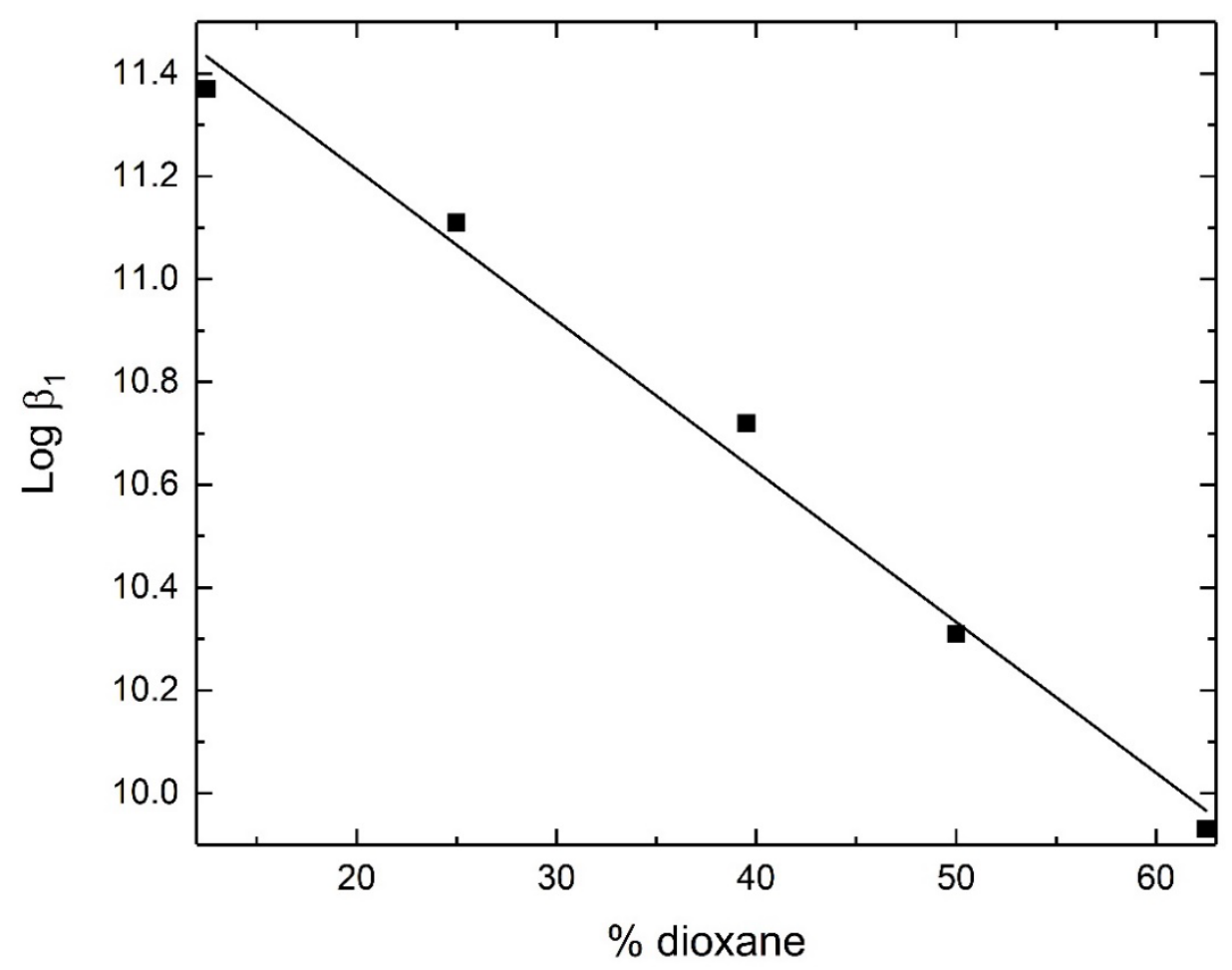

Fig. 4. Plot of $\log \beta_{1} v s$. dioxane percentage for $\left(\mathrm{CH}_{3}\right)_{2} \mathrm{Sn}-\mathrm{Et}_{4} \mathrm{en}$ complex.

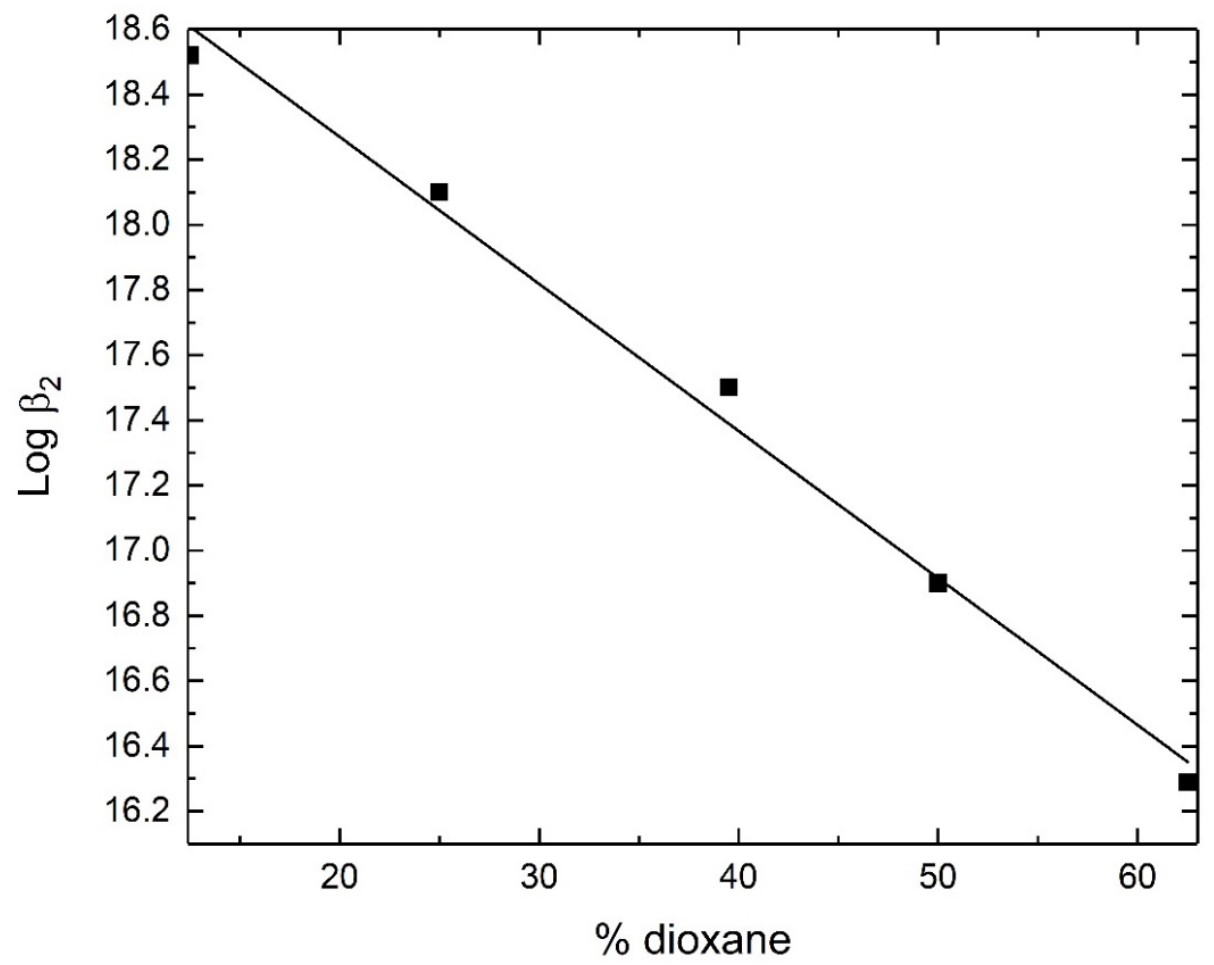

Fig. 5. Plot of Plot of $\log \beta_{2} v s$. dioxane percentage for $\left(\mathrm{CH}_{3}\right)_{2} \mathrm{Sn}-\mathrm{Et} 4 \mathrm{en}$ complex. 


\section{Displacement reaction of coordinated $\mathrm{Et}_{4} \mathrm{en}$ by DNA constituents}

It was reported that $\left(\mathrm{CH}_{3}\right)_{2} \mathrm{Sn}(\mathrm{IV})$ has high affinity for $\mathrm{N}$-donor ligands such as DNA constituents. Such interaction with DNA is thought to be responsible for the anti-tumour activity of related complexes [50]. The mechanism of antitumor activity of $\left(\mathrm{CH}_{3}\right)_{2} \mathrm{Sn}$-(amine) complex is based on the displacement of the amine by DNA. Consequently, the equilibrium constant for such reaction is of biological importance. Consider inosine as a typical DNA constituent (presented by HA) and Et 4 en (presented by B). The equilibria of complexformation and displacement reactions may be presented introductory as:

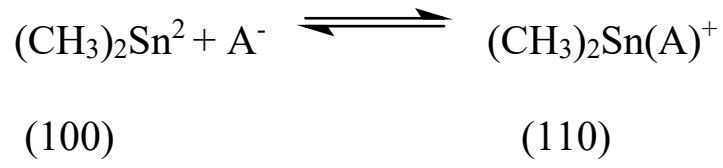

$\left[\left(\mathrm{CH}_{3}\right)_{2} \mathrm{Sn}\right]^{2+}+\mathrm{B} \rightleftharpoons\left(\mathrm{CH}_{3}\right)_{2} \mathrm{SnB}^{2+}$

The equilibrium constant for the displacement reaction is expressed by:

$\mathrm{K}_{\mathrm{eq}}=\left[\left(\mathrm{CH}_{3}\right)_{2} \mathrm{Sn}(\mathrm{A})^{+}\right][\mathrm{B}] /\left[\left(\mathrm{CH}_{3}\right)_{2} \mathrm{Sn}(\mathrm{B})^{2+}\right]\left[\mathrm{A}^{-}\right]$

$\mathrm{K}_{\mathrm{eq}}=\beta_{110}\left[\left(\mathrm{CH}_{3}\right)_{2} \mathrm{Sn}(\mathrm{A})\right]^{+} / \beta_{110}\left[\left(\mathrm{CH}_{3}\right)_{2} \mathrm{Sn}(\mathrm{B})\right]^{2+}$

$\left.\log \mathrm{K}_{\mathrm{eq}}=\log \beta_{110}\left(\mathrm{CH}_{3}\right)_{2} \mathrm{Sn}(\mathrm{A})^{+}-\log \beta_{110} \mathrm{CH}_{3}\right)_{2} \mathrm{Sn}(\mathrm{B})^{2+}$ 
The formation constant value for $\mathrm{Et}_{4}$ en complex, $\left[\left(\mathrm{CH}_{3}\right)_{2} \mathrm{SnB}\right]^{2+}$, amounts to $\log \beta_{110}=11.31$ at $25^{\circ} \mathrm{C}$ (Table 1). The $\log \beta_{110}$ values [51] for $\left(\mathrm{CH}_{3}\right)_{2} \mathrm{Sn}$-DNA constituents complexes $\left[\left(\mathrm{CH}_{3}\right)_{2} \mathrm{SnA}\right]^{+}$together with the equilibrium constants values $\left(\log \mathrm{K}_{\mathrm{eq}}\right.$ ) of displacement reaction calculated by Eq. 12 , are given in Table 4 . The $\mathrm{K}_{\mathrm{eq}}$ values clearly indicate the ability of DNA to displace the coordinated Et $\mathrm{t}_{4} \mathrm{en}$ from its dimethyltin(IV) complex. Also, $\mathrm{K}_{\mathrm{eq}}$ value reveals to what extent the organotin-amine complex could interact with the DNA constituents, the main target in chemotherapy of tumours. The values of equilibrium constant of the displacement reaction for the different DNA constituents are compared. The nucleotide IMP and GMP have the highest values. The extra stability is due to the different columbic force of attraction between the dipositively charged dimethyltin(IV) ion and the nucleotides IMP or GMP having extra negative charges on the phosphate group. Also, the phosphate group of IMP and GMP is acting as anchoring site for tin [52]. This will facilitate the release of coordinated Et 4 en.

Table 4. Equilibrium constants for displacement reaction of coordinated N,N,N',N'tetramethylethylenediamine by DNA constituents at $25^{\circ} \mathrm{C}$ and $0.1 \mathrm{M} \mathrm{NaNO}_{3}$.

\begin{tabular}{|c|c|c|}
\hline DNA & $\begin{array}{c}\log \boldsymbol{\beta}_{\mathbf{1 1}} \mathbf{a}^{\mathbf{a}} \\
\mathbf{D M T - D N A}\end{array}$ & $\log \mathbf{K}_{\mathbf{e q}}$ \\
\hline Inosine & 8.13 & -3.18 \\
\hline Inosine-5' -monophosphate $^{\prime}$ ' monophosphate & 11.90 & 0.59 \\
\hline Guanosine-5' & 12.34 & 1.03 \\
\hline Adenine & 10.01 & -1.30 \\
\hline Adenosine & 4.41 & -6.90 \\
\hline Adenosine -5' -monophosphate & 6.07 & -5.24 \\
\hline Uracil & 9.34 & -1.97 \\
\hline Thymine & 9.61 & -1.70 \\
\hline Thymidine & 9.25 & -2.06 \\
\hline Cytosine & 4.44 & -6.87 \\
\hline Cytidine & 3.77 & -7.54 \\
\hline
\end{tabular}

ataken from ref. [51]

\section{Geometry optimiation}

Calculations of the equilibrium geometries of the complexes and the ligands were carried out by the program Gaussian 09 at the B3LYP level of theory using the bases set LANL2DZ for Sn metal and standard basis set 6-311G* for $\mathrm{C}, \mathrm{H}, \mathrm{N}, \mathrm{O}$ and $\mathrm{Cl}$ atoms. The optimized structures of the ligands and the complexes are given in Fig. 6. The geometric computational parameters for the optimized molecular geometry as bond angles, atomic charges and bond lengths are determined and given in (Tables 5 and 6). The results are interpreted as given in the following:

1- The N-CH $\mathrm{CH}_{2}$ bond length in the complexes $\left(\left(\mathrm{CH}_{3}\right)_{2} \mathrm{Sn}\left(\mathrm{Et}_{4} \mathrm{en}\right) \mathrm{Cl}_{2}, \quad\left(\mathrm{CH}_{3}\right)_{2} \mathrm{Sn}(\mathrm{en})\left(\mathrm{H}_{2} \mathrm{O}\right)_{2}{ }^{2+}\right.$, $\left(\mathrm{CH}_{3}\right)_{2} \mathrm{Sn}\left(\mathrm{Et} t_{4} \mathrm{en}\right)\left(\mathrm{H}_{2} \mathrm{O}\right)_{2}{ }^{2+}$ and $\left.\left(\mathrm{CH}_{3}\right)_{2} \mathrm{Sn}\left(\mathrm{Et}_{4} \mathrm{en}\right)(\mathrm{OH})_{2}\right)$ are $1.50,1.52$ and $1.50 \AA$ respectively. It is longer than the $\mathrm{N}-\mathrm{CH}_{2}$ bond in the free ligand $(1.47 \AA)$. This elongation is due to the bonding of the Nitrogen atom with the metal.

2- The Sn-N bond length in the $\left(\mathrm{CH}_{3}\right)_{2} \mathrm{Sn}\left(\mathrm{Et}_{4} \mathrm{en}\right) \mathrm{Cl}_{2}$ complex $(2.53-2.54 \AA)$ is longer than that in $\left(\mathrm{CH}_{3}\right) \mathrm{Sn}(\mathrm{en}) \mathrm{Cl}_{2}$ complex $(2.40 \AA)$. The main reason of this attributed to the changing the charge density on the nitrogen atom (-0.59 on $\mathrm{N}$ in en compared to -0.10 on $\mathrm{N}$ in $\left.\mathrm{Et}_{4} \mathrm{en}\right)$.

3- The bond angle $\mathrm{Et}_{2} \mathrm{~N}-\mathrm{C}-\mathrm{C}$ in $\mathrm{Et}_{4} \mathrm{en}$ is decreased from $\left(115.8^{\circ}\right)$ upon complexation to $113.4^{\circ}$ $\left(\left(\mathrm{CH}_{3}\right)_{2} \mathrm{Sn}\left(\mathrm{Et}_{4} \mathrm{en}\right) \mathrm{Cl}_{2}\right), 111.8^{\circ}\left(\left(\mathrm{CH}_{3}\right)_{2} \mathrm{Sn}\left(\mathrm{Et}_{4} \mathrm{en}\right)\left(\mathrm{H}_{2} \mathrm{O}\right)_{2}{ }^{2+}\right), 113.6^{\circ}\left(\left(\mathrm{CH}_{3}\right)_{2} \mathrm{Sn}\left(\mathrm{Et}_{4} \mathrm{en}\right)(\mathrm{OH})_{2}\right)$. This may be due to the formation of cyclic compounds.

4- The $\mathrm{H}_{2} \mathrm{O}-\mathrm{Sn}(\mathrm{IV})$ bond length is 2.43-2.47 $\AA$ in $\left(\mathrm{CH}_{3}\right)_{2} \mathrm{Sn}\left(\mathrm{Et} t_{4} \mathrm{en}\right)\left(\mathrm{H}_{2} \mathrm{O}\right)_{2}{ }^{2+}$ species while $2.39 \AA$ in $\left(\mathrm{CH}_{3}\right)_{2} \mathrm{Sn}(\mathrm{en})\left(\mathrm{H}_{2} \mathrm{O}\right)_{2}{ }^{2+}$ species. After deprotonation of coordinated water, the $\mathrm{O}-\mathrm{Sn}(\mathrm{IV})$ bond is 
decreased to $2.00 \AA$ for the two species. This is attributed to the strong bond between the negatively charged $\mathrm{OH}^{-}$ion and $\mathrm{Sn}(\mathrm{IV})$.

Table 5. Calculated $\mathrm{N}-\mathrm{C}, \mathrm{Sn}-\mathrm{N}$ and $\mathrm{Sn}-\mathrm{O}$ bond lengths of the optimized structures of the ligands and complexes according to B3LYP/LanL2DZ level.

\begin{tabular}{|c|c|c|c|c|c|c|}
\hline Spices & \multicolumn{2}{|c|}{$d_{(\mathrm{N}-\mathrm{C})}, \AA$} & \multicolumn{2}{|c|}{$d_{(\mathrm{Sn}-\mathrm{N})}, \AA$} & \multicolumn{2}{|c|}{$d_{(\mathrm{Sn}-\mathbf{O}), \AA} \AA$} \\
\hline \multirow{2}{*}{$\mathrm{Et}_{4} \mathrm{en}$} & $\mathrm{N}(2)-\mathrm{C}(6)$ & 1.47 & \multirow{2}{*}{\multicolumn{2}{|c|}{ (mis }} & \multirow{2}{*}{\multicolumn{2}{|c|}{-}} \\
\hline & $\mathrm{N}(1)-\mathrm{C}(3)$ & 1.47 & & & & \\
\hline \multirow{2}{*}{ En } & $\mathrm{N}(2)-\mathrm{C}(6)$ & 1.47 & \multirow{2}{*}{\multicolumn{2}{|c|}{ - }} & \multirow{2}{*}{\multicolumn{2}{|c|}{-}} \\
\hline & $\mathrm{N}(1)-\mathrm{C}(3)$ & 1.47 & & & & \\
\hline \multirow{2}{*}{$\left(\mathrm{CH}_{3}\right)_{2} \mathrm{Sn}\left(\mathrm{Et}_{4} \mathrm{en}\right) \mathrm{Cl}_{2}$} & $\mathrm{~N}(12)-\mathrm{C}(14)$ & 1.50 & $\operatorname{Sn}(1)-\mathrm{N}(13)$ & 2.59 & \multirow{2}{*}{\multicolumn{2}{|c|}{ - }} \\
\hline & $\mathrm{N}(13)-\mathrm{C}(17)$ & 1.50 & $\operatorname{Sn}(1)-\mathrm{N}(12)$ & 2.63 & & \\
\hline \multirow{2}{*}{$\left(\mathrm{CH}_{3}\right)_{2} \mathrm{Sn}(\mathrm{en}) \mathrm{Cl}_{2}$} & $\mathrm{~N}(13)-\mathrm{C}(17)$ & 1.49 & $\mathrm{Sn}(1)-\mathrm{N}(13)$ & 2.40 & \multirow{2}{*}{\multicolumn{2}{|c|}{ - }} \\
\hline & $\mathrm{N}(12)-\mathrm{C}(14)$ & 1.49 & $\mathrm{Sn}(1)-\mathrm{N}(12)$ & 2.40 & & \\
\hline \multirow{2}{*}{$\left(\mathrm{CH}_{3}\right)_{2} \mathrm{Sn}\left(\mathrm{Et}_{4} \mathrm{en}\right)(\mathrm{H} 2 \mathrm{O})_{2}^{2+}$} & $\mathrm{N}(11)-\mathrm{C}(15)$ & 1.52 & $\mathrm{Sn}(1)-\mathrm{N}(11)$ & 2.33 & $\operatorname{Sn}(1)-\mathrm{O}(48)$ & 2.46 \\
\hline & $\mathrm{N}(10)-\mathrm{C}(12)$ & 1.52 & $\mathrm{Sn}(1)-\mathrm{N}(10)$ & 2.33 & $\mathrm{Sn}(1)-\mathrm{O}(46)$ & 2.43 \\
\hline \multirow{2}{*}{$\left(\mathrm{CH}_{3}\right)_{2} \mathrm{Sn}(\mathrm{en})(\mathrm{H} 2 \mathrm{O})_{2}^{2+}$} & $\mathrm{N}(11)-\mathrm{C}(15)$ & 1.52 & $\mathrm{Sn}(1)-\mathrm{N}(10)$ & 2.28 & $\mathrm{Sn}(1)-\mathrm{O}(22)$ & 2.37 \\
\hline & $\mathrm{N}(10)-\mathrm{C}(12)$ & 1.52 & $\mathrm{Sn}(1)-\mathrm{N}(11)$ & 2.28 & $\mathrm{Sn}(1)-\mathrm{O}(24)$ & 2.37 \\
\hline \multirow{2}{*}{$\left(\mathrm{CH}_{3}\right)_{2} \mathrm{Sn}\left(\mathrm{Et}_{4} \mathrm{en}\right)(\mathrm{OH})_{2}$} & $\mathrm{~N}(11)-\mathrm{C}(15)$ & 1.50 & $\mathrm{Sn}(1)-\mathrm{N}(10)$ & 2.76 & $\mathrm{Sn}(1)-\mathrm{O}(48)$ & 1.99 \\
\hline & $\mathrm{N}(10)-\mathrm{C}(12)$ & 1.50 & $\mathrm{Sn}(1)-\mathrm{N}(11)$ & 2.83 & $\mathrm{Sn}(1)-\mathrm{O}(46)$ & 1.99 \\
\hline \multirow{2}{*}{$\left(\mathrm{CH}_{3}\right)_{2} \mathrm{Sn}(\mathrm{en})(\mathrm{OH})_{2}$} & $\mathrm{~N}(10)-\mathrm{C}(12)$ & 1.49 & $\mathrm{Sn}(1)-\mathrm{N}(10)$ & 2.48 & $\mathrm{Sn}(1)-\mathrm{O}(24)$ & 1.99 \\
\hline & $\mathrm{N}(11)-\mathrm{C}(15)$ & 1.49 & $\mathrm{Sn}(1)-\mathrm{N}(11)$ & 2.48 & $\mathrm{Sn}(1)-\mathrm{O}(22)$ & 1.99 \\
\hline
\end{tabular}

Table 6. Calculated $\mathrm{N}-\mathrm{C}-\mathrm{C}$ bond angles and the nitrogen atom Mulliken charges of the optimized structures of the ligands and complexes according to B3LYP/LanL2DZ level.

\begin{tabular}{|c|c|c|c|c|}
\hline Spices & \multicolumn{2}{|c|}{$\mathbf{N}-\mathbf{C}-\mathbf{C}$ bond angle } & \multicolumn{2}{c|}{ Nitrogen atom charge } \\
\hline \multirow{2}{*}{$E t_{4}$ en } & $\mathrm{C}(6)-\mathrm{C}(3)-\mathrm{N}(1)$ & 115.5 & $\mathrm{~N}(1)$ & -0.10 \\
\cline { 2 - 5 } & $\mathrm{C}(3)-\mathrm{C}(6)-\mathrm{N}(2)$ & 115.9 & $\mathrm{~N}(2)$ & -0.10 \\
\hline \multirow{2}{*}{$\mathrm{En}$} & $\mathrm{C}(6)-\mathrm{C}(3)-\mathrm{N}(1)$ & 110.9 & $\mathrm{~N}(1)$ & -0.63 \\
\cline { 2 - 5 } & $\mathrm{C}(3)-\mathrm{C}(6)-\mathrm{N}(2)$ & 110.9 & $\mathrm{~N}(2)$ & -0.63 \\
\hline \multirow{2}{*}{$\left(\mathrm{CH}_{3}\right)_{2} \mathrm{Sn}\left(\mathrm{Et}_{4} \mathrm{en}\right) \mathrm{Cl}_{2}$} & $\mathrm{C}(14)-\mathrm{C}(17)-\mathrm{N}(13)$ & 113.9 & $\mathrm{~N}(12)$ & -0.26 \\
\cline { 2 - 5 } & $\mathrm{C}(17)-\mathrm{C}(14)-\mathrm{N}(12)$ & 113.1 & $\mathrm{~N}(13)$ & -0.26 \\
\hline \multirow{2}{*}{$\left(\mathrm{CH}_{3}\right)_{2} \mathrm{Sn}\left(\mathrm{Et}{ }_{4} \mathrm{en}\right)(\mathrm{H} 2 \mathrm{O})_{2}^{2+}$} & $\mathrm{C}(12)-\mathrm{C}(15)-\mathrm{N}(11)$ & 111.9 & $\mathrm{~N}(10)$ & -0.39 \\
\cline { 2 - 5 } & $\mathrm{C}(15)-\mathrm{C}(12)-\mathrm{N}(10)$ & 110.9 & $\mathrm{~N}(11)$ & -0.39 \\
\hline \multirow{2}{*}{$\left(\mathrm{CH}_{3}\right)_{2} \mathrm{Sn}(\mathrm{en}) \mathrm{Cl}_{2}$} & $\mathrm{C}(17)-\mathrm{C}(14)-\mathrm{N}(12)$ & 109.5 & $\mathrm{~N}(12)$ & -0.69 \\
\cline { 2 - 5 } & $\mathrm{C}(14)-\mathrm{C}(17)-\mathrm{N}(13)$ & 109.5 & $\mathrm{~N}(13)$ & -0.69 \\
\hline \multirow{2}{*}{$\left(\mathrm{CH}_{3}\right)_{2} \mathrm{Sn}(\mathrm{en})(\mathrm{H} 2 \mathrm{O})_{2}^{2+}$} & $\mathrm{C}(12)-\mathrm{C}(15)-\mathrm{N}(11)$ & 108.8 & $\mathrm{~N}(10)$ & -0.76 \\
\cline { 2 - 5 } & $\mathrm{C}(15)-\mathrm{C}(12)-\mathrm{N}(10)$ & 108.8 & $\mathrm{~N}(11)$ & -0.76 \\
\hline \multirow{2}{*}{$\left(\mathrm{CH}_{3}\right)_{2} \mathrm{Sn}\left(\mathrm{Et} t_{4} \mathrm{en}\right)(\mathrm{OH})_{2}$} & $\mathrm{C}(12)-\mathrm{C}(15)-\mathrm{N}(11)$ & 114.7 & $\mathrm{~N}(10)$ & -0.22 \\
\cline { 2 - 5 } & $\mathrm{C}(15)-\mathrm{C}(12)-\mathrm{N}(10)$ & 113.5 & $\mathrm{~N}(11)$ & -0.20 \\
\hline \multirow{2}{*}{$\left(\mathrm{CH}_{3}\right)_{2} \mathrm{Sn}(\mathrm{en})(\mathrm{OH})_{2}$} & $\mathrm{C}(15)-\mathrm{C}(12)-\mathrm{N}(10)$ & 110.2 & $\mathrm{~N}(10)$ & -0.66 \\
\cline { 2 - 5 } & $\mathrm{C}(12)-\mathrm{C}(15)-\mathrm{N}(11)$ & 110.2 & $\mathrm{~N}(11)$ & -0.66 \\
\hline
\end{tabular}



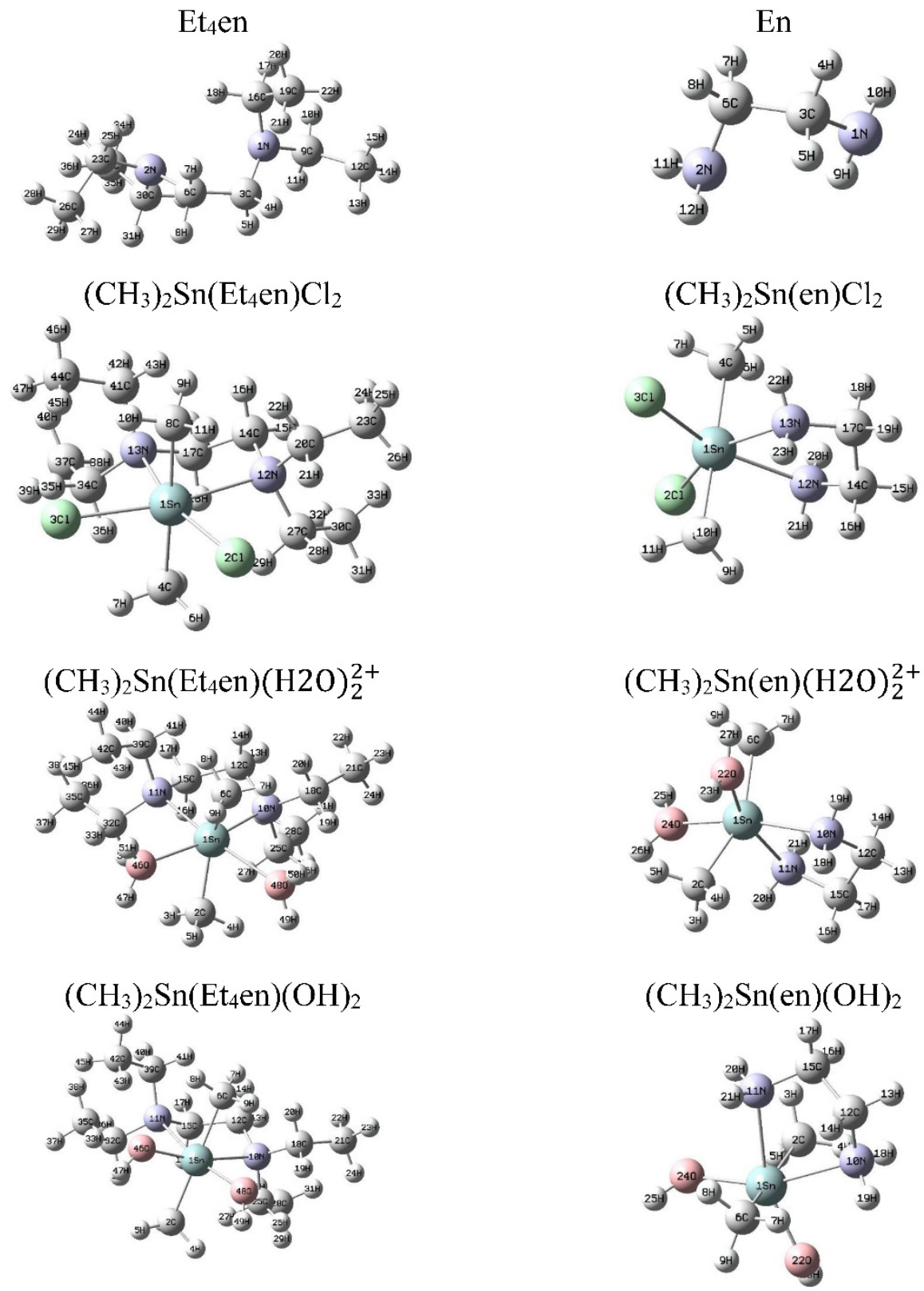

Fig. 6. The optimized structure of ligands and complexes according to B3LYP level of theory using the bases set LANL2DZ for Sn metal and standard basis set 6-311G* for C, H, N, O and $\mathrm{Cl}$ atoms.

Based on the DFT calculation, the polarity of the complexes, is much larger than that for the free ligands as indicated by the dipole moment of the complexes and the ligands (Table 6). On the other hand, the dipole moment of the hydroxo-complexes $\left(\mathrm{CH}_{3}\right)_{2} \mathrm{Sn}\left(\mathrm{Et} \mathrm{t}_{4} \mathrm{en}\right)(\mathrm{OH})_{2}$ and $\left(\mathrm{CH}_{3}\right)_{2} \mathrm{Sn}(\mathrm{en})(\mathrm{OH})_{2}$ are lower than that of the corresponding dichloro-complexes $\left(\mathrm{CH}_{3}\right)_{2} \mathrm{Sn}\left(\mathrm{Et}_{4} \mathrm{en}\right) \mathrm{Cl}_{2}$ (Table 7). This may be described on the assumption that the $\mathrm{O}-\mathrm{Sn}(\mathrm{IV})$ bond is shorter than the $\mathrm{Cl}-\mathrm{Sn}(\mathrm{IV})$ bond as given in Table 5.

The binding energy (BE) of each complex was calculated according to the following equation: 
In equation 13, $\mathrm{E}_{\mathrm{AB}}, \mathrm{E}_{\mathrm{A}}$ and $\mathrm{E}_{\mathrm{B}}$ is the energy of the complex, dimethyltin(IV) species and ligand respectively. The calculated $\mathrm{BE}$ (in $\mathrm{kJ} / \mathrm{mol}$ ) of the complexes $\left(\mathrm{CH}_{3}\right)_{2} \mathrm{Sn}\left(\mathrm{Et}_{4} \mathrm{en}\right) \mathrm{Cl}_{2},\left(\mathrm{CH}_{3}\right)_{2} \mathrm{Sn}(\mathrm{en}) \mathrm{Cl}_{2}$, $\left(\mathrm{CH}_{3}\right)_{2} \mathrm{Sn}\left(\mathrm{Et}_{4} \mathrm{en}\right)(\mathrm{OH})_{2},\left(\mathrm{CH}_{3}\right)_{2} \mathrm{Sn}(\mathrm{en})(\mathrm{OH})_{2},\left(\mathrm{CH}_{3}\right)_{2} \mathrm{Sn}\left(\mathrm{Et}_{4} \mathrm{en}\right)(\mathrm{H} 2 \mathrm{O})_{2}^{2+}$ and $\left(\mathrm{CH}_{3}\right)_{2} \mathrm{Sn}(\mathrm{en})(\mathrm{H} 2 \mathrm{O})_{2}^{2+}$ are $-52.4,-$ $99.2,-4.2,-31.0,-400.1$ and -382.8 , respectively. The negative values of the $\mathrm{BE}$ indicate that the complexes are stable.

Table 7. The calculated energies and dipole moments for of the ligands and complexes according to B3LYP/LanL2DZ level.

\begin{tabular}{|c|c|c|c|c|c|}
\hline Spices & $\mathbf{E}^{\mathbf{a}}$ & HOMO & LUMO & $\Delta \mathbf{E}$ & Dipole moment \\
\hline$E t_{4}$ en & -504.9 & -4.84 & 2.76 & 7.60 & 0.69 \\
\hline $\mathrm{En}$ & -190.5 & -5.51 & 2.70 & 8.21 & 1.05 \\
\hline$\left(\mathrm{CH}_{3}\right)_{2} \mathrm{Sn}\left(\mathrm{Et}_{4} \mathrm{en}\right) \mathrm{Cl}_{2}$ & -618.1 & -6.54 & -0.11 & 6.43 & 12.38 \\
\hline$\left(\mathrm{CH}_{3}\right)_{2} \mathrm{Sn}(\mathrm{en}) \mathrm{Cl}_{2}$ & -303.7 & -6.64 & 0.08 & 6.72 & 12.47 \\
\hline$\left(\mathrm{CH}_{3}\right)_{2} \mathrm{Sn}\left(\mathrm{Et} \mathrm{en}_{4}\right)(\mathrm{OH})_{2}$ & -739.8 & -5.90 & 0.90 & 6.80 & 6.54 \\
\hline$\left(\mathrm{CH}_{3}\right)_{2} \mathrm{Sn}(\mathrm{en})(\mathrm{OH})_{2}$ & -425.4 & -5.88 & 1.39 & 7.27 & 7.33 \\
\hline
\end{tabular}

${ }^{a} \mathrm{E}$ : is the total energy (a.u.), HOMO: is the highest occupied molecular orbital (eV), LUMO: is the lowest unoccupied molecular orbital $(\mathrm{eV}), \Delta \mathrm{E}$ : $\mathrm{E}_{\mathrm{LUMO}}-\mathrm{EHOmo}_{\mathrm{eV}}$ ) and dipole moment calculated (Debye).

\section{Calculated infrared spectra of ligands and complexes}

The experimental counterparts of the calculated IR spectra results are currently not available for comparison and it will be considered in our future work. Therefore, we will discuss the calculated IR spectra of the complexes from the theoretical point of view only. The calculated IR spectra of the free ligands and the complexes are shown in Fig. 7. There are no imaginary vibrational frequencies observed in all calculated spectra of the ligands and complexes. The assignments of the calculated vibrational frequencies of the free ligands and their complexes are listed in Table 8 . The theoretical assignments are easily obtained by the visualization of the normal mode displacement vectors utilizing the GaussView program. The assignments listed in Table 8 are only for the vibrational modes of the amino group vibrations because they are the most sensitive to changes upon the metal-nitrogen interactions. Also, the $\mathrm{Sn}-\mathrm{N}, \mathrm{Sn}-\mathrm{OH}, \mathrm{Sn}-\mathrm{Cl}$ and $\mathrm{Sn}-\mathrm{OH}_{2}$ stretching vibrations are identified. In the spectra of the $\left.\mathrm{CH}_{3}\right)_{2} \mathrm{Sn}(\mathrm{en}) \mathrm{Cl}_{2},\left(\mathrm{CH}_{3}\right)_{2} \mathrm{Sn}(\mathrm{en})(\mathrm{H} 2 \mathrm{O})_{2}^{2+}$ and $\left(\mathrm{CH}_{3}\right)_{2} \mathrm{Sn}(\mathrm{en})(\mathrm{OH})_{2}$ complexes the $\beta_{\mathrm{s}}\left(\mathrm{NH}_{2}\right)$ vibration is shifted to higher wave frequency in comparison with that found in the free en ligand (Table 8). Also for the same complexes the $v(\mathrm{C}-\mathrm{N})$ vibration mode is shifted to lower wave frequency in comparison with that of free en ligand. However, in the case of $\left(\mathrm{CH}_{3}\right)_{2} \mathrm{Sn}\left(\mathrm{Et}_{4} \mathrm{en}\right) \mathrm{Cl}_{2},\left(\mathrm{CH}_{3}\right)_{2} \mathrm{Sn}(\mathrm{Et} 4 \mathrm{en})\left(\mathrm{H}_{2} \mathrm{O}\right)_{2}{ }^{2+}$ and $\left(\mathrm{CH}_{3}\right)_{2} \mathrm{Sn}\left(\mathrm{Et} \mathrm{t}_{4} \mathrm{en}\right)(\mathrm{OH})_{2}$ complexes this vibrational mode $(\mathrm{v}(\mathrm{C}-\mathrm{N}))$ is shifted to higher frequency in comparison with that of free $\mathrm{Et}_{4} \mathrm{en}$ ligand. In the spectra of all complexes the $v_{\mathrm{as}}(\mathrm{C}-\mathrm{C}-\mathrm{N}$ vibration mode is shifted to lower frequency in comparison with those of free en and $\mathrm{Et}_{4} \mathrm{en}$ ligands. The above mentioned shifts of these vibrational modes can be attributed to the coordination of the nitrogen atom with the metal.

Table 8. Calculated infrared absorption $\left(\mathrm{cm}^{-1}\right)$ data for the ligands and complexes.

\begin{tabular}{|c|c|c|c|c|c|c|c|c|c|}
\hline Compounds & $v(\mathrm{Sn}-\mathrm{Cl})$ & $\begin{array}{c}v(\mathrm{Sn}- \\
\mathrm{OH})\end{array}$ & $\begin{array}{c}v \\
(\mathrm{Sn}- \\
\left.\mathrm{OH}_{2}\right)\end{array}$ & $\begin{array}{l}v(\mathrm{Sn}- \\
\mathrm{N})\end{array}$ & $\begin{array}{l}\text { Vas }(\mathrm{Sn} \\
\left.-\mathrm{CH}_{3}\right)\end{array}$ & $\begin{array}{c}\mathrm{v}_{\mathrm{s}}(\mathrm{Sn} \\
\left.-\mathrm{CH}_{3}\right)\end{array}$ & $\begin{array}{c}\beta_{\mathrm{s}}\left(\mathrm{NH}_{2}\right. \\
)\end{array}$ & $\begin{array}{c}\mathbf{v} \\
(\mathrm{C}- \\
\mathrm{N})\end{array}$ & $\begin{array}{c}\operatorname{Vas}(\mathbf{C} \\
-\mathrm{C}- \\
\mathrm{N})\end{array}$ \\
\hline $\mathrm{Et}_{4} \mathrm{en}$ & - & - & - & - & - & - & - & 1021 & 1157 \\
\hline En & - & - & - & - & - & - & 1670 & 1066 & 1172 \\
\hline $\begin{array}{c}\left(\mathrm{CH}_{3}\right)_{2} \mathrm{Sn}\left(\mathrm{Et}_{4} \mathrm{en}\right) \\
\mathrm{Cl}_{2}\end{array}$ & 261 & - & - & $\begin{array}{l}576 \\
612 \\
\end{array}$ & 537 & 471 & - & 1035 & 1133 \\
\hline
\end{tabular}




\begin{tabular}{|c|c|c|c|c|c|c|c|c|c|}
\hline$\left(\mathrm{CH}_{3}\right)_{2} \mathrm{Sn}(\mathrm{en}) \mathrm{Cl}_{2}$ & 260 & & - & 285 & 552 & 490 & 1696 & 1027 & 1135 \\
\hline $\begin{array}{c}\left(\mathrm{CH}_{3}\right)_{2} \mathrm{Sn}(\mathrm{Et}+\mathrm{en}) \\
(\mathrm{H} 2 \mathrm{O})_{2}^{2+}\end{array}$ & - & - & $\begin{array}{l}246 \\
242\end{array}$ & $\begin{array}{c}510 \\
594\end{array}$ & 579 & 499 & - & 1036 & 1136 \\
\hline $\begin{array}{c}\left(\mathrm{CH}_{3}\right)_{2} \mathrm{Sn}(\mathrm{en}) \\
(\mathrm{H} 2 \mathrm{O})_{2}^{2+}\end{array}$ & - & - & $\begin{array}{l}244 \\
249\end{array}$ & 331 & 555 & 512 & 1696 & 1012 & 1064 \\
\hline $\begin{array}{c}\left(\mathrm{CH}_{3}\right)_{2} \mathrm{Sn}(\mathrm{Et} \text { en }) \\
(\mathrm{OH})_{2}\end{array}$ & - & $\begin{array}{l}519 \\
524\end{array}$ & - & $\begin{array}{l}568 \\
603\end{array}$ & 541 & 466 & - & 1067 & 1131 \\
\hline $\begin{array}{c}\left(\mathrm{CH}_{3}\right)_{2} \mathrm{Sn}(\mathrm{en})(\mathrm{O} \\
\mathrm{H})_{2}\end{array}$ & - & $\begin{array}{l}524 \\
527\end{array}$ & - & 355 & 534 & 475 & 1691 & 1006 & 1131 \\
\hline
\end{tabular}

a: Calculated value according to B3LYP/LANL2DZ level, $\mathrm{n}_{\mathrm{s}}$ : symmetric stretching, $\mathrm{n}_{\text {as: }}$ asymmetric stretching $\mathrm{n}$ : stretching, $\beta_{\mathrm{s}}$ : scissoring
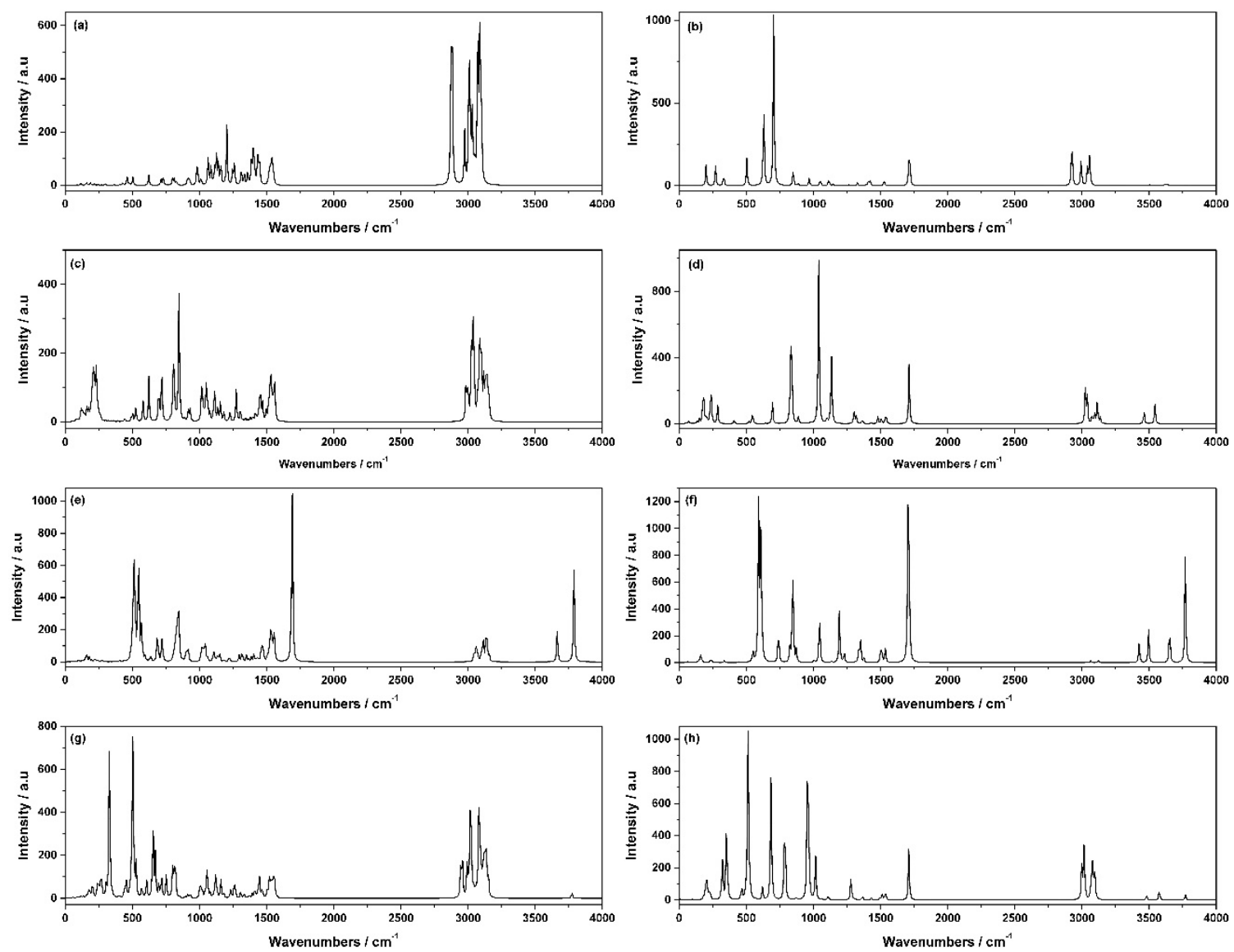

Fig. 7. Calculated Infrared spectra of the (a) Et 4 en ligand, (b) En ligand, (c) $\left(\mathrm{CH}_{3}\right)_{2} \mathrm{Sn}\left(\mathrm{Et}_{4} \mathrm{en}\right) \mathrm{Cl}_{2}$ complex, (d) $\left(\mathrm{CH}_{3}\right)_{2} \mathrm{Sn}(\mathrm{en}) \mathrm{Cl}_{2}$ complex, (e) $\left(\mathrm{CH}_{3}\right)_{2} \mathrm{Sn}\left(\mathrm{Et}_{4} \mathrm{en}\right)(\mathrm{H} 2 \mathrm{O})_{2}^{2+}$ complex, (f) $\left(\mathrm{CH}_{3}\right)_{2} \mathrm{Sn}(\mathrm{en})(\mathrm{H} 2 \mathrm{O})_{2}^{2+}$ complex, (g) $\left(\mathrm{CH}_{3}\right)_{2} \mathrm{Sn}\left(\mathrm{Et} t_{4} \mathrm{en}\right)(\mathrm{OH})_{2}$ complex and $(\mathbf{h})\left(\mathrm{CH}_{3}\right)_{2} \mathrm{Sn}(\mathrm{en})(\mathrm{OH})_{2}$ complex according to B3LYP level of theory using the bases set LANL2DZ for Sn metal and standard basis set 6-311 $\mathrm{G}^{*}$ for $\mathrm{C}, \mathrm{H}, \mathrm{N}, \mathrm{O}$ and $\mathrm{Cl}$ atoms. 


\section{Conclusion}

The present investigation reports the complex formation equilibria of dimethyltin(IV) with N,N,N',N'tetraethylethylenediamine and its parent ethylenediamine. The results show the formation of 1:1 complex and the mono- and dihydroxo- species. The effect of solvent polarity on the stability of the complexes was discussed. The thermodynamic parameters of the complexes as $\Delta \mathrm{H}^{\circ}$ and $\Delta \mathrm{S}^{\circ}$ were determined and discussed. The displacement reaction of Et $\mathrm{e}_{4}$ coordinated to dimethyltin (IV) by DNA constituents was investigated. IMP and GMP have the highest tendency to displace Et 4 en. The geometric parameters, bond angle, atomic charge and bond lengths were computed and interpreted. The results of the present study are expected to contribute to the chemistry of diorgantin (IV) as potential antitumours.

\section{References}

1. Gasser, G.; Ott, I.; Metzler-Nolte, N. J. Med. Chem. 2011, 54, 3-25 DOI: https://doi.org/10.1021/jm100020w

2. Gianferrara, T.; Bratsos, I.; Alessio, E. Dalton Trans. 2009, 7588-7598 DOI: https://doi.org/10.1039/b905798f

3. Moody, L.; Holder, A. A. Annu. Rep. Prog. Chem., Sect. A 2009, 105, 505-524 DOI: https://doi.org/10.1039/b818288b

4. Hadjikakou, S.K.; Hadjiliadis, N. Coord. Chem. Rev. 2009, 253, 235-249 DOI: https://doi.org/10.1016/j.ccr.2007.12.026

5. Tabassum, S.; Pettinari, C. J. of Organomet. Chem. 2006, 691, 1761-1766 DOI: https://doi.org/10.1016/j.jorganchem.2005.12.033

6. Pellerito, C.; Nagy, L.; Pellerito, L.; Szorcsik, A. J. of Organomet. Chem. 2006, 691, 1733-174 DOI: https://doi.org/10.1016/j.jorganchem.2005.12.025

7. Gielen, M.; Biesemans, M.; Willem, R. Appl. Organometal. Chem. 2005; 19, 440-450 DOI: https://doi.org/10.1002/aoc.771

8. Pellerito, L.; Nagy, L. Coord. Chem. Rev.2002, 224, 111-150 DOI: https://doi.org/10.1016/S00108545(01)00399-X

9. Clarke, M. J.; Zhu, F.; Frasca, D. R. Chem. Rev. 1999, 99, 2511-2533 DOI: https://doi.org/10.1021/cr9804238

10. Gielen, M. Coord. Chem. Rev. 1996, 151, 41-51.

11. Sadler, P.J. Adv. Inorg. Chem. 1991, 36, 1-48 DOI: https://doi.org/10.1016/S0898-8838(08)60035-5

12. Guo, Z.; Sadler, P.J. Angew. Chem. Int. Ed. 1999, 38, 1512-1531 DOI: https://doi.org/10.1002/(SICI)1521-3773(19990601)38:11<1512::AID-ANIE1512>3.0.CO;2-Y

13. Tlahuext-Aca, A.; Höpfl, H.; Medrano-Valenzuela, F.; Guerrero-Alvarez, J.; Tlahuext, H.; Ochoa Lara, K.; Reyes-Márquez, V.; Tlahuextl, M. Z. Anorg. Allg. Chem. 2012, 638, 1-9

14. Kotsakis, A.; Hatzidaki, D.; Vamvakas, L.; Vardakis, N.; Kalykaki, A.; Bozionelou, V.; Androulakis, N.; Kalbakis K.; Saridaki, Z.; Georgoulias, V. Anticancer Res., 2010, 30, 4335-4342 DOI: https://doi.org/10.1002/zaac.201200099

15. Gielen, M.; Willem, R. Anticancer Research, 1992, 12, 269-271.

16. Crowe, A. J. Antitumour activity of tin compounds, in: Metal Compounds in Cancer Therapy, Springer, 1994, 147-179.

17. Crowe, A. J.; Smith, P. J.; Cardin, C. J.; Parge, H. E.; Smith, F. E. Cancer Lett. 1984, 24, 45-48 DOI: https://doi.org/10.1016/0304-3835(84)90078-8 
18. Gielen, M.; Meriem, A.; Boualam, M.; Willem, R. In vivo (Athens, Greece) 1993, 7, 171-174.

19. Yahyi, A.; Et-Touhami, A.; Yahyaoui, R.; Touzani, R. Lett. Drug Des. Discovery 2010, 7, 534-540.

20. Muhammad, N.; Shah, A.; Shuja, S.; Ali, S.; Qureshi, R.; Meetsma, A.; Tahir, M.N. J. Organomet. Chem. 2009, 694, 3431-3437 DOI: https://doi.org/10.1016/j.jorganchem.2009.06.036

21. Mohamed, M. M. A.; Shehata, M. R.; Shoukry, M. M. J. Coord. Chem. 2001, 53, $125-142$ DOI: https://doi.org/10.1080/00958970108022607

22. Al Alousi, A. S.; Shehata, M. R.; Shoukry, M. M.; Mohamed, N. M. Chem. Speciation Bioavailability 2009, 21, 1-6 DOI: https://doi.org/10.3184/095422909X416216

23. Al-Najjar, A.; Mohamed, M. M. A.; Shehata, M. R.; Shoukry, M. M. Ann. Chim. (Rome, Italy) 2006, 96, 97-107 DOI: https://doi.org/10.1002/adic.200690010

24. Al-Najjar, A.; Mohamed, M. M. A.; Shoukry, M. M. J. of Coord. Chem. 2006, 59, $193-206$ DOI: http://dx.doi.org/10.1080/00958970500270786

25. Mohamed, M. M. A.; Shoukry, M. M. Chem. Pharm. Bull. 2001, 49, 253-257 DOI: https://doi.org/10.1248/cpb.49.253

26. Shehata, M. R.; Mohamed, M. M. A.; Shoukry, M. M.; Hussein, M. A.; Hussein, F. M. J. Coord. Chem. 2015, 68, 1101-1114 DOI: http://dx.doi.org/10.1080/00958972.2015.1007962

27. 27.Bates, R. Theory and Practice Wley, New York, Sydney (1964).

28. 28.Motekaitis, R. J.; Martell, A. E.; Nelson, D. A. Inorg. Chem. 1984, 23, 275-283 DOI: https://doi.org/10.1021/ic00171a005

29. Shoukry, M. M.; Shehata, M. R.; Hamza, M. S.; van Eldik, R. Dalton Trans. 2005, 3921-3926 DOI: http://dx.doi.org/10.1039/b510553f

30. Gans, P.; Sabatini, A.; Vacca, A. Inorg. Chim. Acta 1976, 18, 237-239 DOI: https://doi.org/10.1016/S0020-1693(00)95610-X

31. L. Pettit, Personal communication, 1993.

32. Robb, M. A.; Cheeseman, J. R.; Scalmani, G.; Barone, V.; Mennucci, B.; Petersson, G. A.; Nakatsuji, H.; Caricato, M.; Li, X.; Hratchian, H. P.; Izmaylov, A. F.; Bloino, G. Z. J.; Sonnenberg, J. L.; Hada, M.; Ehara, M.; Toyota, K.; Fukuda, R.; Hasegawa, J.; Ishida, M.; Nakajima, T.; Honda, Y.; Kitao, O.; Nakai, H.; Vreven, T.; Montgomery, J. A.; Peralta, Jr. J. E.; Ogliaro, F.; Bearpark, M.; Heyd, J. J.; Brothers, E.; Kudin, K. N.; Staroverov, V. N.; Kobayashi, R.; Normand, J.; Raghavachari, K.; Rendell, A.; Burant, J. C.; Iyengar, S. S.; Tomasi, J.; Cossi, M.; Rega, N.; Millam, J. M.; Klene, M.; Knox, J. E.; Cross, J. B.; Bakken, V.; Adamo, C.; Jaramillo, J.; Gomperts, R., Stratmann, R. E.; Yazyev, O.; Austin, A. J.; Cammi, R.; Pomelli, C.; Ochterski, J. W.; Martin, R. L.; Morokuma, K.; Zakrzewski, V. G.; Voth, G. A.; Salvador, P.; Dannenberg, J. J.; Prich, S. D.; Daniels, A. D.; Farkas, O.; Foresman, J. B.; Ortiz, J. V.; Cioslowski, J.; Fox, D. J. Wallingford CT, Gaussian Inc. 2009.

33. Lee, C.; Yang, W.; Parr, R. G. Phys. Rev. B 1988, 37, 785-789 DOI: https://doi.org/10.1103/PhysRevB.37.785

34. Becke, A. D. J. Chem. Phys 1993, 98, 5648-5652 DOI: https://doi.org/10.1063/1.464913

35. Becke, A.D. J. Chem. Phys. 1996, 104, 1040-1046 DOI: http://dx.doi.org/10.1063/1.470829

36. Hay, P. J.; Wadt, W. R. J. Chem. Phys. 1985, 82, 270-283 DOI: http://dx.doi.org/10.1063/1.448799

37. Wadt, W. R.; Hay, P. J. J. Chem. Phys. 1985, 82, 284-298 DOI: http://dx.doi.org/10.1063/1.448800

38. Hay, P. J.;Wadt, W. R. J. Chem. Phys. 1985, 82, 299-310 DOI: http://dx.doi.org/10.1063/1.448975

39. Perrin, D. D. Stability Constants of Metal-ion Complexes. Part B. Organic Ligand IUPAC Chemical Data Series, No. 22. Pergamon Press, Oxford, 1979.

40. Arena, G.; Calì, R.; Contino, A.; Musumeci, A.; Musumeci, S.; Purrello, R. Inorg. Chim. Acta 1995, 237, 187-191 DOI: https://doi.org/10.1016/0020-1693(95)04655-S 
41. Natsume, T.; Aizawa, S. I.; Hatano, K.; Funahashi, S. Dalton Trans. 1994, 2749-2753 DOI: https://doi.org/10.1039/DT9940002749

42. Buzás, N.; Gajda, T.; Nagy, L.; Kuzmann, E.; Vertes, A.; Burger, K. Inorg. Chim. Acta 1998, 274, 167- 176 DOI: https://doi.org/10.1016/S0020-1693(97)06044-1

43. De Stefano, C.; Foti C.; Gianguzza A.; Martino M.; Pellerito L.; Sammartano S. J. Chem. Eng. Data 1996, 41, 511-515 DOI: https://doi.org/10.1021/je9502915

44. Foti, C.; Gianguzza, A.; Millero, F.; Sammartano, S. Aquat. Geochem.1999, 5, 381-398.

45. Rees, D. O. J. Mol. Biol. 1980, 141, 323-326 DOI: https://doi.org/10.1016/0022-2836(80)90184-9

46. Rogers, N. K.; Roore, G. R.; Strenberg, M. J. E. J. Mol. Biol. 1985, 182 , 613-616 DOI: https://doi.org/10.1016/0022-2836(85)90248-7

47. Sigel, H.; Martin, R. B.; Tribolet, R.; Haring, U. K.; Malini-Balakrishrann, R. Eur. J. Biochem. 1985, 152, 187-193 DOI: https://doi.org/10.1111/j.1432-1033.1985.tb09180.x

48. Åkerlöf, G.; Short, O. A. J. Am. Chem. Soc. 1936, 58, 1241-1243 DOI: https://doi.org/10.1021/ja01298a044

49. Shoukry, M. M.; El-Medani, S. M. Collect. Czech. Chem. Commun. 1997, 62, 1023-1028 DOI: https://doi.org/10.1135/cccc19971023

50. Mun, L. C.; Hapipah, M. A.; Shin, S. K. Appl. Organometal. Chem. 2012, 26, 310-319 DOI: https://doi.org/10.1002/aoc.2862

51. Al-Flaijj, O.; Shehata, M. R.; Mohamed, M. M. A.; Shoukry, M. M. Monatsh. Chem. 2001, 132, 349366. DOI: https://doi.org/10.1007/s007060170

52. Nath, M.; Singh, H.; Eng, G.; Song. X. Inorg. Chem. Commun. 2011, 14, 1381-1385 DOI: https://doi.org/10.1016/j.inoche.2011.05.027 